\title{
Review \\ Seaweed Exhibits Therapeutic Properties against Chronic Diseases: An Overview
}

\author{
Maria Dyah Nur Meinita $1,2,3, * \mathbb{B}$, Dicky Harwanto ${ }^{1,4}$ and Jae-Suk Choi $1,5, *$ (i)
}

1 Seafood Research Center, Industry Academy Cooperation Foundation (IACF), Silla University, 606, Advanced Seafood Processing Complex, Wonyang-ro, Amnam-dong, Seo-gu, Busan 49277, Korea; dickyharwanto5@gmail.com

2 Faculty of Fisheries and Marine Science, Jenderal Soedirman University, Purwokerto 53123, Indonesia

3 Center for Maritime Bioscience Studies, Jenderal Soedirman University, Purwokerto 53123, Indonesia

4 Faculty of Fisheries and Marine Science, Diponegoro University, Semarang 50275, Indonesia

5 Department of Food Biotechnology, College of Medical and Life Sciences, Silla University, 140, Baegyang-Daero 700 Beon-Gil, Sasang-gu, Busan 46958, Korea

* Correspondence: maria.meinita@unsoed.ac.id (M.D.N.M.); jsc1008@silla.ac.kr (J.-S.C.); Tel.: +62-281-642-360 (M.D.N.M.); +82-512-487-789 (J.-S.C.)

check for updates

Citation: Meinita, M.D.N.; Harwanto, D.; Choi, J.-S. Seaweed Exhibits

Therapeutic Properties against

Chronic Diseases: An Overview. Appl. Sci. 2022, 12, 2638. https://doi.org/ 10.3390/app12052638

Academic Editor: Anabela

Raymundo

Received: 6 December 2021

Accepted: 1 March 2022

Published: 3 March 2022

Publisher's Note: MDPI stays neutral with regard to jurisdictional claims in published maps and institutional affiliations.

Copyright: () 2022 by the authors. Licensee MDPI, Basel, Switzerland. This article is an open access article distributed under the terms and conditions of the Creative Commons Attribution (CC BY) license (https:// creativecommons.org/licenses/by/ $4.0 /)$.

\begin{abstract}
Seaweeds or marine macroalgae are known for producing potentially bioactive substances that exhibit a wide range of nutritional, therapeutic, and nutraceutical properties. These compounds can be applied to treat chronic diseases, such as cancer, cardiovascular disease, osteoporosis, neurodegenerative diseases, and diabetes mellitus. Several studies have shown that consumption of seaweeds in Asian countries, such as Japan and Korea, has been correlated with a lower incidence of chronic diseases. In this study, we conducted a review of published papers on seaweed consumption and chronic diseases. We used the Preferred Reporting Items for Systematic Reviews and Meta-Analyses (PRISMA) method for this study. We identified and screened research articles published between 2000 and 2021. We used PubMed and ScienceDirect databases and identified 107 articles. This systematic review discusses the potential use of bioactive compounds of seaweed to treat chronic diseases and identifies gaps where further research in this field is needed. In this review, the therapeutic and nutraceutical properties of seaweed for the treatment of chronic diseases such as neurodegenerative diseases, obesity, diabetes, cancer, liver disease, cardiovascular disease, osteoporosis, and arthritis were discussed. We concluded that further study on the identification of bioactive compounds of seaweed, and further study at a clinical level, are needed.
\end{abstract}

Keywords: macroalgae; seaweed; bioactive; nutrient; therapeutic

\section{Introduction}

Numerous scientific articles have been published on functional foods with putative beneficial health properties. The term "functional food" was coined as a result of widespread interest in specific foods that may promote health [1]. These properties are due to the ability of a food item to lower the risk of chronic diseases and help manage such diseases, thereby improving quality of life [1,2]. According to a global analysis of new functional food categories, products focused on digestive health capture the interest of a broader audience than products with a narrow focus, such as products targeting specific illnesses [3].

Seaweeds or macroalgae are regarded as one of the non-animal foods of the future based on their ability to grow without the need for arable land or freshwater resources, thereby avoiding competition with traditional crops [4-6]. Currently, seaweeds are particularly appealing because of their high nutrient and bioactive phytochemical content [7]. The active components of seaweed, such as sulfated polysaccharides [8], polyphenols [9], fucosterol [10], fucoxanthin [11], fucoidan [12], phlorotannin [13], and flavonoids [14], may 
lead to the development of novel drugs and functional foods, or nutraceuticals that may be used as a natural alternative to commercial synthetic drugs for certain chronic diseases [15]

In recent years, the food industry has increased the development and marketing of a wide range of functional food products using diverse food sources [16]. Functional food is defined as food containing one or more ingredients that provide health benefits in addition to energy and nutrition [17]. Conventional foods containing bioactive components can also be promoted as having positive health benefits. Some may be fortified or enhanced foods, created specifically to reduce disease risk in a specific group of people [3]. Seaweed has been consumed as a food in Asian countries since ancient times, particularly in China, Japan, and Korea [15]. In China, since $600 \mathrm{BC}$, seaweed has been served to honored guests, even to the King himself [18]. In Japan, Sargassum fusiforme (Hijiki), Eisenia bicyclis (Arame), Saccharina japonica (Kombu or Haidai), Undaria pinnatifida (Wakame or Quandai-cai), Ulva pertusa (ao-nori) and Porphyra sp. (nori) have been employed in ordinary cooking since the 8 th century. As people from these countries have migrated around the world, this custom has moved with them, so that today there are more countries where seaweed is commonly consumed [19]. Coastal residents in South Asian countries, such as Indonesia, Malaysia, Philippines, Vietnam, and Thailand also eat fresh Gracilaria or Caulerpa seaweed, especially as an ingredient in salads. Some kelp species, such as Alaria esculenta and Himantalia elongate, are also consumed in European countries.

Seaweed has also been used in traditional Eastern medicine owing to its beneficial health effects [20]. In Western countries, seaweed has mostly been used in the food, cosmetics, and pharmaceutical industries as a source of functional polysaccharides (e.g., agar, carrageenans, and alginates) [21,22]. However, edible seaweeds are increasingly being consumed in Europe, especially in France; in the United States and South American countries, they are considered to be novel functional foods $[15,21]$. Several studies have revealed that dietary habits and traditional culture in consuming seaweed in Asian countries, especially in Japan and Korea, are correlated with a lower incidence of chronic diseases such as cancer, cardiovascular disease, hypertension, osteoporosis, and obesity [6,23-27]. Several studies have also revealed that consumption of seaweed can reduce the occurrence of chronic pathologies, including neurodegenerative diseases [28], cardiovascular disease [29], obesity [30], diabetes [14], cancer [31], liver disease [32], osteoporosis [33], and arthritis [34]. Furthermore, collaborative cohort studies have been conducted to investigate the effect of the seaweed diet in Japan and Korea, and the results of these studies showed that seaweed-containing diets are related to protection against cancer (Iso and Kubota 2007; Kim et al. 2020c). Thus, seaweed consumption appears to have an important impact on the occurrence of chronic diseases. The aim of this study is to review the potential of seaweed and seaweed-derived bioactive compounds to prevent and treat chronic diseases. This comprehensive review collected the available data from published papers to identify gaps where further research is required.

\section{Materials and Methods}

This study followed the Preferred Reporting Items for Systematic Reviews and MetaAnalyses (PRISMA) method [35]. The literature search was conducted using PubMed and ScienceDirect as online databases for collecting and screening the research articles that met the criteria. The criteria included article type, year of publication, language used, and topic. We screened the research articles that used English, were published between 2000 and 2021, and where the topic met our scope. To screen the topic, we used specific keywords which were found in the titles, abstracts, or text content. The keywords "seaweed" and "macroalgae" were combined with other keywords such as nutritional, bioactive compound, chronic disease, neurodegenerative disease, cardiovascular disease, obesity, diabetes, cancer, liver disease, osteoporosis, and arthritis. Articles that met the requirements were analyzed, extracted, and reviewed. 


\section{Results}

A systematic review of the published studies yielded 213 articles. Then, through identification, screening, eligibility, and inclusion, 107 articles that fulfilled the review criteria were selected. Previous studies have observed that the use of seaweed modulates several common chronic diseases, including diabetes, neurodegenerative diseases, obesity, cancer, liver disease, cardiovascular disease, osteoporosis, and arthritis (Figure 1). Most of the studies were conducted using in vitro (39.4\%) and in vivo (36.4\%) models, and only $2.3 \%$ of the studies that we found were clinical studies.

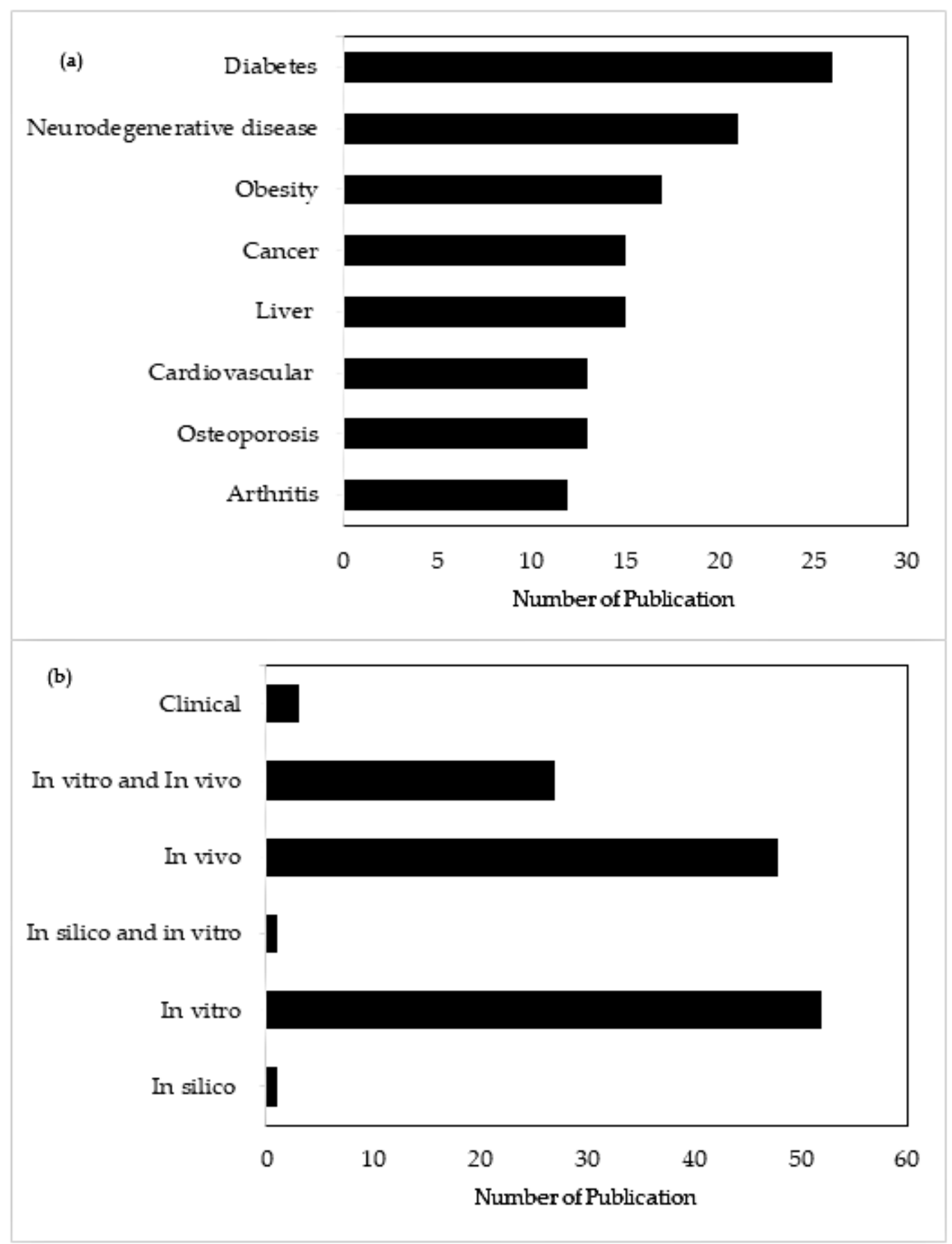

Figure 1. Number of publications on functional seaweed and chronic disease based on (a) the type of chronic disease and (b) the experimental model. 
We summarized seaweed research on chronic disease based on three groups of seaweeds: brown (Phaeophyceae), red (Rhodophyceae), and green (Chlorophyceae) (Figure 2). Studies of chronic disease were conducted on brown seaweed (68\%), red seaweed (18\%), and green seaweed (14\%). Among the brown seaweeds, the most studied species were Ecklonia (21.3\%), Sargassum (20.2\%), and Fucus (9\%). In red seaweed, Gracilaria (20.8\%) and Gelidium (16.7\%) were the top two most studied species for potential use in the treatment of chronic diseases. The most studied green seaweed species were Ulva (47.4\%), Codium (26.3\%), and Caulerpa (15.8\%). The phylum of Phaeophyta was the most studied species on cancer $(40 \%)$, diabetes $(85 \%)$, arthritis $(67 \%)$, neurodegenerative diseases $(71 \%)$, obesity (59\%), osteoporosis (46\%), liver disease (80\%) and cardiovascular disease (84\%). The studies of seaweed in treating chronic diseases were conducted in vivo, in vitro, in silico and as clinical studies. There was a lack of clinical studies conducted; however, a clinical study was conducted to test a Maritech ${ }^{\circledR}$ seaweed extract formulation containing extract of Fucus vesiculosis, Macrocystis pyrifera, and Laminaria japonica on osteoarthritis patients [36]. The study showed that seaweed extract can reduce the symptoms of osteoarthritis in a dose-dependent manner.
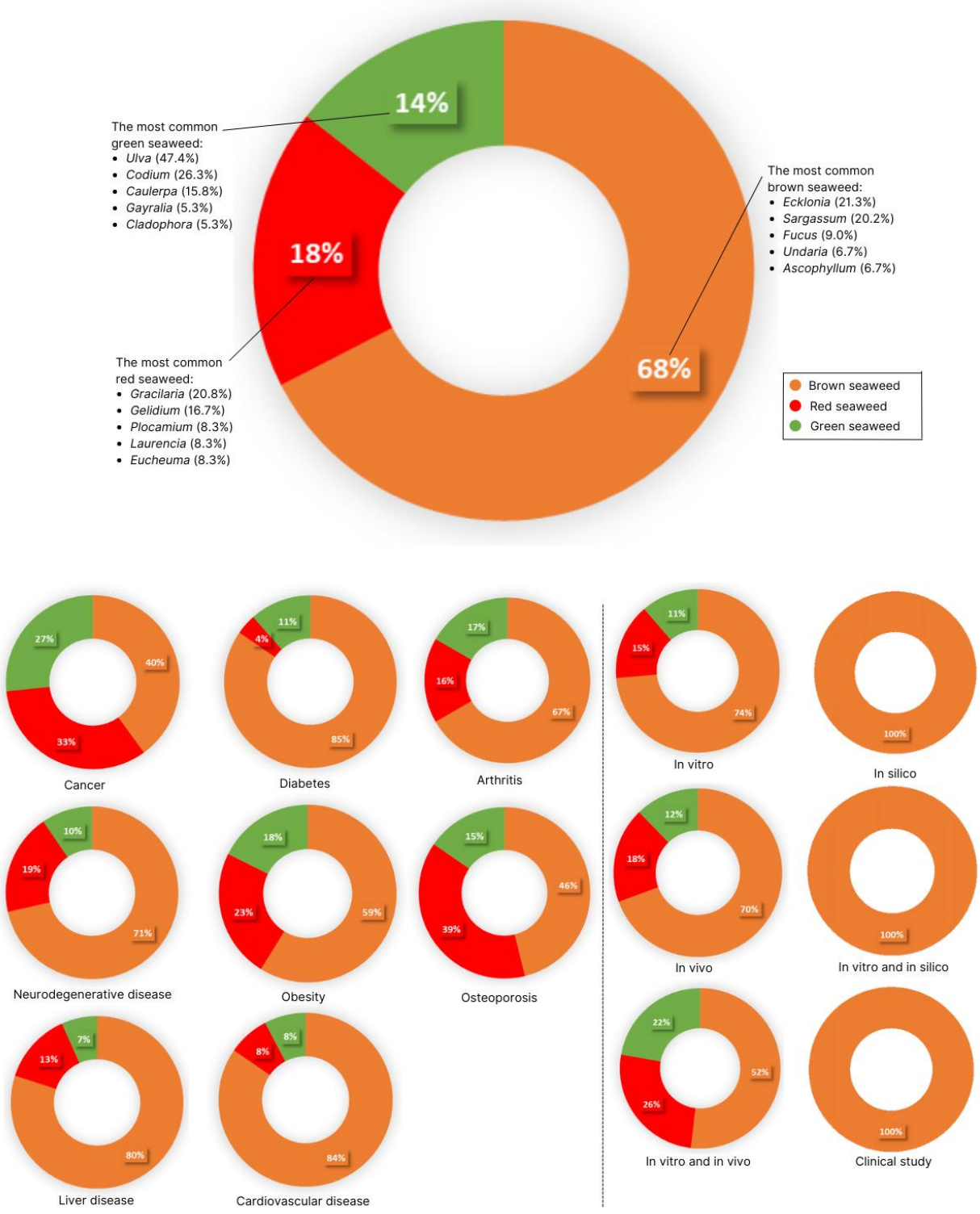

Figure 2. Percentage of published papers of seaweed research on chronic disease based on (a) the phyla Chlorophyta (green color), Rhodophyta (red color), and Phaeophyta (brown color); (b) chronic disease for each phylum; and (c) experimental model for each phylum. 


\section{Nutritional Value of Seaweed}

Seaweed contains a variety of important macro- and micronutrients, including proteins, carbohydrates, phenols, vitamins, and minerals [37,38]. However, the biochemical composition of seaweeds is affected by the species, time of collection, and habitat, as well as by external factors such as temperature, light intensity, and nutrient concentration in water. For example, a study by Garcia-Vaquero et al. [37] reported that the proximate composition of dry matter of Laminaria digitata, Laminaria hyperborea, and Ascophyllum nodosum was highest in the autumn period. While the study conducted by Khairy and El-Shafay [39] showed that the protein, carbohydrate, lipid, ash, fatty acid and amino acid content of Ulva lactuca, Jania rubens, and Pterocladia capillacea varied throghout different seasons. Physcio-chemical parameters also influence the biochemical composition of red seaweed Catenella repens [40].

\subsection{Carbohydrates}

In seaweed, the carbohydrate content is high, the majority of which is dietary fiber and is not absorbed by the human body [1]. The carbohydrate of seaweed is different from the carbohydrate of land-plants. In seaweed, the storage of carbohydrates has an important function in photosynthesis and osmoregulation. The type and amount of carbohydrate content in seaweed also vary based on many factors such as the type of seaweed, and physical, chemical, and biological factors. Most of the red seaweeds contain sulfated galactan (agar and carrageenan), and some of the brown seaweeds contain sulfated fucans and alginates, while cellulose has commonly been found in large amounts in green seaweed [41].

Carbohydrates in seaweed are found in large amounts, including monosaccharides, disaccharides, and polysaccharides; however, their composition depends on many factors. The components of monosaccharides, such as galactose, glucose, mannose, xylose, fructose, fucose, and arabinose, were found in the total sugars of seaweed [42,43]. The most representative polysaccharides in seaweed are agar, alginates, ulvan, and carrageenans $[44,45]$. Total polysaccharide content ranges from $4 \%$ to $76 \%$ of dry weight $(\mathrm{dw})$, with the highest content found in the genera Ascophyllum, Porphyra, and Palmaria. In general, green seaweed genera such as Ulva also have a high content, which can be up to $65 \%$ of dw [1]. For example, the carbohydrate contents of Ulva rigida and Ulva pertusa are $58 \% \mathrm{dw}$ and $56 \% \mathrm{dw}$, respectively $[4,46]$. Other studies reported high carbohydrate content in Gracilaria fisheri and Gracilaria tenuistipitata, of $63 \%$ and $59 \% \mathrm{dw}$, respectively [47]. For brown seaweed, Hizikia fusiforme exhibited a very high amount of carbohydrates, with a value of $72 \% \mathrm{dw}$ [48].

\subsection{Proteins and Amino Acids}

Among seaweeds, red seaweed contains the highest protein content, which ranges from $0.67 \%$ to $45.0 \% \mathrm{dw}$, followed by green seaweed $(3.42-29.80 \% \mathrm{dw})$ and brown seaweed $(5.02-19.66 \% \mathrm{dw})$ [49]. Specifically, the protein content of red seaweed varies, with values of $9.32 \% \mathrm{dw}$ for Gelidium latifolium, $15.58 \% \mathrm{dw}$ for Gracilaria verrucosa [50], and $26.69 \% \mathrm{dw}$ for Plocamium telfairiae [51]. Green seaweeds such as Caulerpa lentillifera, Ulva rigida, and Ulva pertusa contain protein contents of $7 \%, 9.3 \%$, and $21.5 \% \mathrm{dw}$, respectively $[4,46]$. The protein contents of brown seaweeds Hizikia fusiforme and Fucus vesiculosus were reported to be $12.2 \%$ [52] and $15.1 \% \mathrm{dw}$ [4], respectively. The protein content of seaweed also depends on the season. For example, Palmaria palmata (Dulse) collected on the French Atlantic coast during winter and spring, exhibited a higher protein content $(21.9 \% \mathrm{dw})$ than dusring the summer and autumn months $(11.9 \% \mathrm{dw})$, with essential amino acids constituting $26 \%$ to $50 \% \mathrm{dw}$ of the protein [53]. Several studies have examined the amino acid composition of seaweeds, and aspartic acid, glutamic acid, taurine, threonine, arginine, and alanine have been reported to be high in concentration. To compare, the concentrations of aspartic acid and threonine in Ulva armoricana, Ulva Pertusa, Palmaria palmata, and Porphyra tenra were found to be much higher than in leguminous plants and ovalbumin [54]. Finally, glutamic and aspartic acids seem to be the most abundant amino acids in most seaweeds [55]. The reference nutrient intake (RNI) for protein is a 5 -g portion equal to a maximum of $1.97 \%$, $4.5 \%$, and $2.98 \% \mathrm{dw}$ from brown, red, and green seaweed, respectively. The digestibility 
of protein in edible seaweed species ranged from $14.7 \%$ to $86.2 \% \mathrm{dw}$, with Porphyra tenera showing the highest value [49].

\subsection{Lipids and Fatty Acids}

Generally, total lipids found in seaweed range between $0.3 \%$ and $7.0 \% \mathrm{dw}$ [15]. A previous study reported that Undaria pinnatifida contains lipids comprising 3.71\% dw [56]. In contrast, the lipid content of Ulva rigida, Gracilaria sp., Fucus vesiculosus, and Saccharina latissima ranged from $0.4 \%$ to $2.8 \% \mathrm{dw}$ [4].

Polyunsaturated fatty acids (PUFAs) are common lipids found in seaweed, and are of great interest due to their biological activity. In seaweeds, PUFAs contain a substantial amount of $\omega-3$ fatty acids for almost half of the total lipid content [57]. Seaweed also contains sterol, an important lipid of various types. Brown seaweeds primarily contain fucosterol, while cholesterol is the predominant sterol type in red seaweeds $[3,58,59]$. Taken together, many essential fatty acids found in seaweeds could be combined to increase their efficacy as a dietary supplement or as part of a well-balanced diet.

\subsection{Ash}

The ash content of seaweed is quite high compared to common land plants, ranging from $8.0 \%$ to $48.68 \% \mathrm{dw}[15,50]$. However, this amount depends on several factors. The ash content of Saccharina latissima, Laminaria spp., and Alaria esculenta was lowest in September, October, and November, and highest in spring (February to June); however, it only varied slightly throughout the year. For these species, total dry weight was lowest from January to March and highest from July to September [1]. Peñalver and colleagues [60] reviewed natural products from many seaweed species and demonstrated that brown seaweed contains more ash in general. Moreover, proximate analysis on red seaweed found an average value for ash content of $22.9 \pm 10.99 \mathrm{~g} / 100 \mathrm{~g}$, which is much higher than that in terrestrial plants [61]. These results were confirmed in red seaweed Gelidium elegans, containing $24.1 \%$ ash $\mathrm{dw}$ [62], and the total ash of Gracilaria verrucosa reached as high as $48.68 \% \mathrm{dw}[50]$.

\subsection{Moisture}

The moisture of seaweed is influenced by many factors, especially postharvest treatment. Drying method is the main factor that might influence the moisture of seaweed. Some fresh seaweeds have a moisture content of $80-90 \%$, whereas seaweeds that are dried by air have a moisture level of $10-20 \%$ [21,63]. A nutritional analysis of selected Azorean macroalgae (Ulva compressa, Ulva rigida, Gelidium microdon, and Pterocladiella capillacea) reported that moisture content varied between $83.2 \%$ and 90.0\% [15]. Holdt and Kraan [1] reported that water content was lower in some species, but not less than $68.0 \% \mathrm{dw}$.

\subsection{Dietary Fiber}

Non-digestible carbohydrates and lignin are considered dietary fibers [64]. Unlike sugar or starch, dietary fiber cannot be directly digested by digestive enzymes. In seaweed, dietary fiber consists mostly of carrageenan and agar (red seaweed), alginate (brown seaweed), and ulvans (green seaweed), which represent $25 \%$ to $75 \%$ dw [65]. According to their solubility in water, fibers are classified as soluble dietary fiber (SDF) or insoluble dietary fiber (IDF). Seaweed dietary fiber content is similar to or higher than that of terrestrial plants. The SDF content is typically higher in red seaweeds, such as Chondrus and Porphyra (15-22\% dw). The brown seaweeds Fucus and Laminaria/Saccharina have higher IDF contents (27-40\% dw) [60]. Research by Neto et al. [4] demonstrated that among four seaweeds, the brown seaweed Fucus vesiculosus contains the highest total fiber, with a value of $45 \% \mathrm{dw}$. Dietary fiber intake for Asians is recommended to be met by consuming $8 \mathrm{~g}$ of seaweed, which can meet up to $12.5 \%$ of daily requirements [66]. In addition, dietary fiber can generally retain oil and water, which is beneficial for promoting digestive health. 


\subsection{Minerals and Vitamins}

Seaweeds are rich sources of important minerals and vitamins. However, amounts vary according to seaweed species, phylum, season, and environmental, geographical, and physiological factors. In particular, seaweeds contain substantial amounts of calcium $(\mathrm{Ca})$, magnesium $(\mathrm{Mg})$, sodium $(\mathrm{Na})$, phosphorus $(\mathrm{P})$, iodine $(\mathrm{I})$, zinc $(\mathrm{Zn})$, and iron $(\mathrm{Fe})$, at much higher levels than in terrestrial plants. $\mathrm{Ca}$ and $\mathrm{Mg}$ were found to be the major minerals in seaweed. A study of several seaweeds from the Kenyan Coast demonstrated that brown seaweed (Hypnea musciformis and Sargassum oligocystum) and red seaweed (Laurencia intermedia) contain high amounts of $\mathrm{Ca}$ and $\mathrm{Mg}$ [67]. Calcium phosphate is more bioavailable in seaweeds than calcium carbonate, which is found in milk [57]. MacArtain and colleagues [66] demonstrated that $8 \mathrm{~g}$ of Ulva lactuca (sea lettuce), which provides $260 \mathrm{mg}$ of $\mathrm{Ca}$, provides approximately $37 \%$ of the RNI of Ca for an adult male, while cheddar cheese only provides $5 \%$ of the RNI in the same portion. Furthermore, seaweed also contains one of the best natural sources of $\mathrm{P}$, which is beneficial in the human diet. According to the World Health Organization (WHO) and Food and Agriculture Organization (FAO), the dietary reference value of $\mathrm{P}$ for adults ( $>13$ years) is $700 \mu \mathrm{g} /$ day [7]. Brown algae have been identified as important sources of I for the prevention and treatment of iodine deficiency goiters. The daily intake of I for adults is $150 \mu \mathrm{g} /$ day, and excessive consumption should be avoided [7]. Ca and P are essential for heart and smooth muscle contraction, as well as for the skeleton. $\mathrm{Mg}$ is an important cofactor of many enzymes, including those involved in cellular respiration, while $\mathrm{Na}$ is responsible for maintaining the body's water and electrolyte balance. A high intake of $\mathrm{Ca}, \mathrm{Na}$, and $\mathrm{K}$ is linked to a lower mean systolic pressure and a lower risk of hypertension [7].

Edible seaweeds are also a valuable source of vitamin content, particularly watersoluble vitamin C and B complexes and the fat-soluble vitamins A and E [21]. A study on several red seaweeds showed that, in general, the concentration of vitamin $C$ was higher than that of vitamin A and vitamin E [61]. Research by Rajapakse and Kim [57] reported that red and brown algae are rich in vitamin $C$ and $A$. Undaria pinnatifida and Porphyra umbilicalis are rich in B vitamins [7]. Vitamins A, B, C, and E are important antioxidants produced by seaweeds. Vitamin A is found in large amounts in Fucus spiralis (1.41 mg/100 g of dry weight), Osmundea pinnatifida (1.20 mg/100 g of dry weight), and Porphyra/Pyropia spp. (1.27 mg/100 g of dry weight). Vitamin C is present in large amounts in Ulva lactuca (10 mg/8 $\mathrm{g}$ of dry weight) and Undaria pinnatifida (14 mg/100 $\mathrm{g}$ of dry weight). Vitamin B12 is abundant in species such as Ulva spp. and Porphyra/Pyropia spp., with a recommended dietary allowance (RDA) of $2.5 \mathrm{mg}$ /day for adults [66]. These findings indicate that seaweed minerals and vitamins have a greater potential to be exploited in high-demand functional food categories.

\section{Bioactive Compounds in Seaweed}

Seaweed are potential source of bioactive compounds including fucoidan, agars, kappa carrageenans, ulvans, alginates, laminarin, fucosterol, phlorotannins, lectins, alkaloids, diterpenes, and fucoxanthin (Figure 3). 
<smiles>C=S(=O)(O)O[C@@H]1[C@@H](C)O[C@H](C)[C@H](O)[C@H]1O</smiles>

1<smiles>CC1(C)CCCC2(C)C[C@]34CC(c5ccc(C(=O)O)nc5O)C(C(O)O)O[C@]3(C)CC[C@]124</smiles>

4

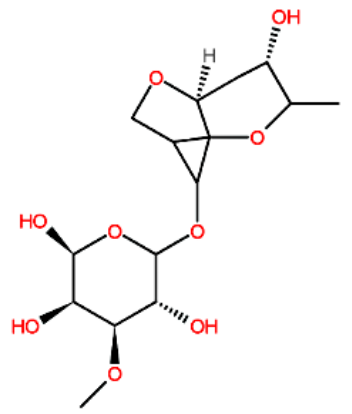

2

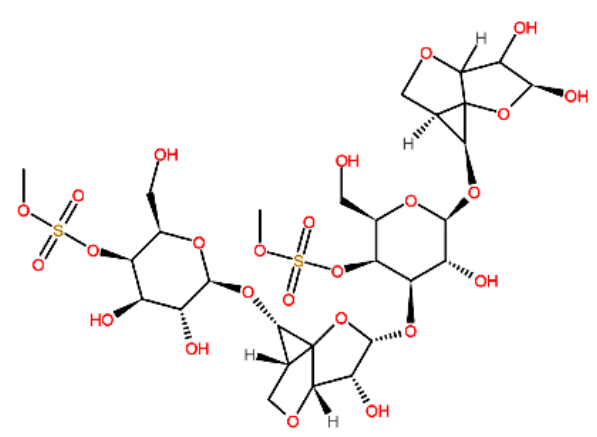

3

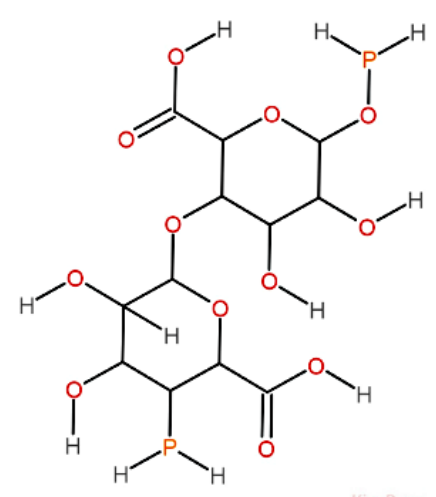

5

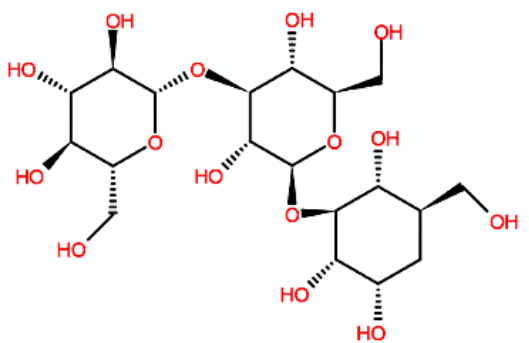

6

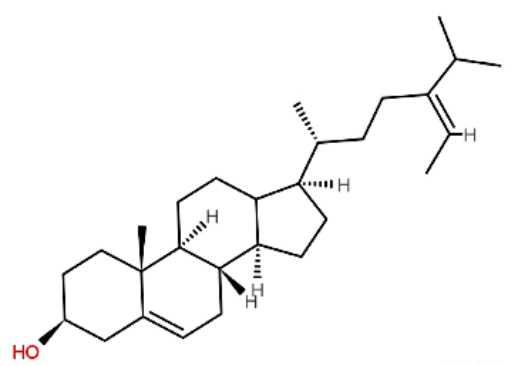

7<smiles>Oc1cc(O)cc(O)c1</smiles>

8

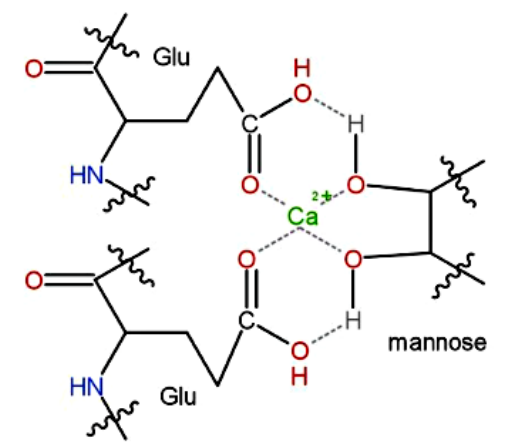

9<smiles>CN[C@@H](C)[C@H](O)c1ccccc1</smiles>

10<smiles>CC1=CC[C@H]2CC3(C)C(CC[C@H]13)C2(C)C</smiles>

11<smiles>[Y9]C(C)=C(C)C(C)=C(C)C(C)=C(C)C(C)=C(C)C(C)=C(C)C(C)=C(C)C(C)=C(C)C(C)=C(C)C(=O)CC12OC1(C)CC(C)CC2(C)C</smiles>

Figure 3. The chemical structures of fucoidan (1), agars (2), kappa carrageenans (3), ulvans (4), alginates (5), laminarin (6), fucosterol (7), phlorotannins (8), lectins (9), alkaloids (10), diterpenes (11), and fucoxanthin (12). 


\subsection{Fucoidan}

Fucoidan is a high-molecular-weight polysaccharide found in brown seaweeds, such as Fucus serratus, Ascophyllum nodosum, and Undaria pinnatifida [68]. Fucoidan is made up of two chains: one with $(1 \rightarrow 3)-\alpha$-L-fucopyranose as the main chain and one with $\alpha$-L-fucopyranose linked by $(1 \rightarrow 3)$ and $(1 \rightarrow 4)$ as the main chain. Single and double substitutions in the sulfate groups of both skeletons can occur at the C-2 or C-4 positions. Some fucoidans have substituted branches at positions C-2 and C-3 [69]. Fucoidans are the most abundant polysaccharides in brown seaweeds, followed by alginates and laminarans; however, their contents vary depending on the species, geographical area, harvest season, and environmental factors such as salinity and nutrients [70]. Fucoidan is a large part of the cell wall comprised of carbohydrate and sulfate content. For example, Hizikia fusiformis contains $99 \% \mathrm{dw}$ fucoidan [48], whereas Ascophyllum nodosum contains $84.6 \%$ $\mathrm{dw}$ fucoidan [71]. Several studies have reported numerous pharmacological properties of fucoidans such as antioxidant, anti-inflammatory, anticoagulant, antimicrobial, anticancer, immunomodulatory, and hepatoprotective activities [72-77].

\subsection{Agars}

Agar is a linear polysaccharide derived from the cell walls of red seaweeds Gelidium and Gracilaria [78]. Agar is composed of alternating 3,6-anhydro-L-galactose and D-galactose units linked by $\alpha-(1,3)$ and $\beta-(1,4)$ glycosidic bonds [79], and is popular as a phycocolloid consisting mainly of agarose and agaropectin units [78]. Removal of the agaropectin component from agar yields agarose [80]. The quality of the agar is determined by the type, pattern, and degree of substitution, as well as molecular weight, chemical composition (pyruvate, methoxyl, and sulfate), and physical properties (gel strength, gel syneresis, viscosity, gel temperature, and melting temperature), which determine its market value [81]. Agar is generally used as an additive in the food industry because of its gelling ability, and agar and its derivatives have received increasing attention for therapeutic purposes, apart from their rheological properties [80].

\subsection{Carrageenans}

Carrageenan is a hydrocolloid consisting of sulfated galactans with alternating (1-4)anhydro-D-galactose and (1-3)-D-galactose backbones isolated from red seaweeds (Rhodophyceae) [82]. Carrageenan is generally considered safe for routine use as a gelling agent and thickener in foods [83]. Based on their chemical structure and properties, carrageenans are divided into kappa $(\kappa)$, iota $(\mathrm{l})$, and lambda $(\lambda)$, which have one, two, and three sulfate groups per disaccharide unit, respectively [83,84]. Kappa carrageenans form the strongest gels of any carrageenan, which makes them useful in the food, dairy, and pharmaceutical industries as thickeners, gelling agents, and stabilizers [85]. Kappaphycus alvarezii and Eucheuma denticulatum [84] are the most important commercially cultivated warm-water carrageenan species, producing kappa- and iota-carrageenan, respectively. These seaweeds are mainly grown commercially in Indonesia, the Philippines, Malaysia, Brazil, and Tanzania [86].

\subsection{Ulvans}

Ulvans are highly contentious sulphated polyelectrolytes with gelling properties that can be extracted from green seaweeds, which are mainly composed of rhamnose (5.0-92.2 mol\%), glucuronic acid (2.6-52.0 mol\%), iduronic acid $(0.6-15.3 \mathrm{~mol} \%)$, and xylose $(0.0-38.0 \mathrm{~mol} \%)$ as the main monomer sugars [87]. Ulvans also contain a common constituting disaccharide, such as aldobiuronic acid, $(1 \rightarrow 4)$-D-glucuronic acid-( $1 \rightarrow 4)$ - Lrhamnose-3-sulfate- $(1 \rightarrow]$, and iduronic acid [45]. The average molecular weight of ulvans ranges from 189 to $8.200 \mathrm{kDa}$ [88]. Ulva cell-wall polysaccharides account for $38 \%$ to $54 \%$ of dry algal matter [88]. Ulvans are mainly found in Ulva sp. with high amounts of water-soluble ulvan and insoluble cellulose, as well as a minor amount of peculiar alkali-soluble linear xyloglucan and glucuronan [42]. In this regard, ulvan exhibits potent 
applications in biomaterial science (wound dressings, biofilm prevention, excipients, and tissue engineering), pharmaceuticals (antiviral, antioxidant, antihyperlipidemic, anticancer, anticoagulant, and immunostimulatory), functional foods, and agriculture [65,87].

\subsection{Alginates}

Alginates, which are primarily found in brown algae, are linear polysaccharides with varying mannuronic and glucuronic acid ratios [65]. This ratio varies between brown algae species, and can be determined using proton nuclear magnetic resonance $\left({ }^{1} \mathrm{H}\right.$ NMR). The monomers in alginate, b-d-mannuronic acid (M) and its C-5 epimer $\alpha$-l-guluronic acid (G), can be arranged in varying proportions to form a chain bound by $1 \rightarrow 4$ linkages [42]. The $\mathrm{M}$ and $\mathrm{g}$ residues are organized into blocks of consecutive $\mathrm{M}$ (M-blocks), consecutive $\mathrm{g}$ (G-blocks), or alternating $\mathrm{M}$ and $\mathrm{g}$ residues (MG-blocks). Alginate is a phycocolloid that can be dissolved in water to produce a gel with specific rheological properties. Ascophyllum, Laminaria, and Mycrocystis are the most common commercial sources of phaeophytes for alginates, and Sargassum, Durvillea, Eklonia, Lessonia, and Turbinaria as minor sources [89]. Alginate has also been extensively researched as a biomaterial in biomedical science because of its biocompatibility, low toxicity, and easy availability [80]. The pharmacological properties of alginate as immunomodulatory, antioxidant, and anticoagulant agents have been developed in recent years [70].

\subsection{Laminaran}

Laminaran is a glucan, built up from a homopolymer of $\beta$-d-glucose ( $\beta$-glucan) linked by a $1 \rightarrow 3$ glycosidic linkage (in some cases, having $1 \rightarrow 6$ linkages that form a branch and ramifications in the O-6 position), which may contain a mannitol unit or a few uronic acid residues at their reducing end [70]. The average molecular weight of laminaran is $5 \mathrm{kDa}$ [42]. Laminaran can be found in the fronds of Laminaria/Saccharina and, to a lesser extent, Ascophyllum, Fucus, and Undaria. The content varies seasonally and by habitat, but it can reach up to $32 \%$ of the dry weight [45]. Laminaran does not gel or form viscous solutions, and its main application may be in medical and pharmaceutical applications.

\subsection{Phytosterols}

Seaweeds contain large amounts of phytosterols, such as fucosterol, which is the main sterol in brown algae and cholesterol in red algae; however, the sterol composition of green algae is relatively heterogeneous, with a complex mixture of 28-isofucosterol, ergosterol, $\beta$-sitosterol, poriferasterol, cholesterol, and others [90,91]. These compounds may have particular biological activities, including antioxidant, antidiabetic, anti-inflammatory, anticancer, hepatoprotective, and anti-Alzheimer's disease activity [92]. However, accurate determination of the biological activity of individual phytosterols is currently difficult because of the high cost and scarcity of pure phytosterols [93]. Fucosterol and 24-methylenecholesterol are sterols found in brown algae such as Sargassum fusiforme and Undaria pinnatifida, which have been linked to a variety of health benefits in humans [94]. A feasible, economical, and efficient technique for the rapid extraction of phytosterol may be conducted using microwave-assisted extraction coupled with high-speed counter-current chromatography [95].

\subsection{Phlorotannins}

Marine algae contain bioactive polyphenolic molecules that can modulate biological properties, such as phlorotannins. Phlorotannins are tannin derivatives composed of phloroglucinol-based phenolics (1,3,5-trihydroxybenzene) that are synthesized through the acetate-malonate pathway [94]. They are thought to be the defense compounds in brown seaweeds with high concentrations (up to $25 \%$ ), and are stored in special vesicles (physodes) [4]. A variety of phlorotannins has been discovered, including eckol, phlorofucofuroeckol A, dieckol, 6,6-bieckol, 8,8-bieckol, 7-phloroeckol, fucodiphloroethol G, phloroglucinol, and bifuhalol [96-99]. These compounds exhibit a variety of biological activ- 
ities, including high antioxidant activity [100]; inhibition of $\alpha$-amylase, $\alpha$-glucosidase, and lipase, which are key enzymes in obesity and diabetes control [96,101,102]; and neuroprotective activities [97,98]. Phlorotannins were found to be non-toxic in cell lines, invertebrates, microalgae, seaweeds, plants, animals (fish, mice, rats, and dogs), and humans [99].

\subsection{Carotenoids}

Carotenoids are fat-soluble, highly unsaturated red, orange, or yellow pigments composed of isoprenoids, and their basic structure consists of eight isoprene units with a C 40 backbone [103]. Carotenoids are naturally present in plants, fungi, bacteria, and algae. Several types of carotenoids produced by seaweeds are $\beta$-carotene and zeaxanthin (red seaweed), fucoxanthin (brown seaweed), and siphonaxanthin (green seaweed). Fucoxanthin is one of the most abundant marine carotenoids with different health benefits, including anti-oxidative activity [104], and significantly reduces animal weight gain [105]. Furthermore, fucoxanthin can protect neuronal cells from oxidative-stress-induced neurotoxicity $[106,107]$. Siphonaxanthin is a marine carotenoid and a derivative of lutein found in green algae, such as Caulerpa lentillifera, Codium cylindricum, and Codium fragile [108]. The characteristic structure of siphonaxanthin is a keto group located at C-8 and an extra hydroxyl group at C-19 [109].

\subsection{Lectins}

Lectins are sugar-binding proteins, useful for deciphering the glycocode [10]. They are found in most organisms, from viruses and bacteria to plants and animals [110]. In general, marine algal lectins have low molecular weights compared to land-plant lectins, and they appear to induce negligible immunogenicity due to their small size. Furthermore, due to the presence of disulfide bonds and high specificity for complex carbohydrates over monosaccharides, marine algae lectins have greater molecular stability than plant lectins [111]. Lectins have biotechnological significance in a variety of fields, such as biochemistry, agriculture, and pharmacology, including nociception and inflammation [112].

\subsection{Alkaloids}

Bisindole alkaloids are a large group of structurally diverse secondary metabolites produced by a diverse range of organisms from both terrestrial and marine environments. Numerous unique bisindole alkaloids, including meridianins, topsentins, nortopsentins, dragmacidins, variolins, and rhopaladins, have been reported from sponges, actinomycetes, tunicates, and green algae [113]. Furthermore, some of these marine bisindole compounds have been discovered to have potent and diverse bioactive properties, such as antifungal, antibacterial, antiviral, cytotoxic, anti-inflammatory, and notable antitumor properties [114].

\subsection{Halogenated Compounds}

Terpenes are compounds found in seaweeds, consisting of two, three, four, or six isoprene units. Sesquiterpenes are terpenes with antibacterial, antifungal, and anti-inflammatory properties [115]. Eleganolone and eleganonal belong to the family of diterpenes, and are usually found in Bifurcaria bifurcata [116]. Diterpenes are non-volatile halogenated compounds with xenicane, dolabellane, and prenylated guaiane skeletons with different structures. Brown algae from the genus Dictyota are highly abundant in diterpenes. Dictyodial, dictyol C, and dictyol $\mathrm{H}$, which are algal terpenes, have previously been isolated from various Dictyota species. These secondary metabolites deter feeding by marine herbivores [94].

\section{Pharmacological Properties of Seaweed to Overcome Chronic Disease}

Numerous studies have reported the pharmacological properties of seaweed for the treatment of chronic diseases, such as neurodegenerative diseases, cardiovascular diseases, obesity, diabetes, cancer, liver disease, osteoporosis, and arthritis. The bioactive compounds contained in seaweed are suggested to be beneficial for the management of chronic diseases. The mechanisms of each of these chronic diseases are shown in Figure 4. 


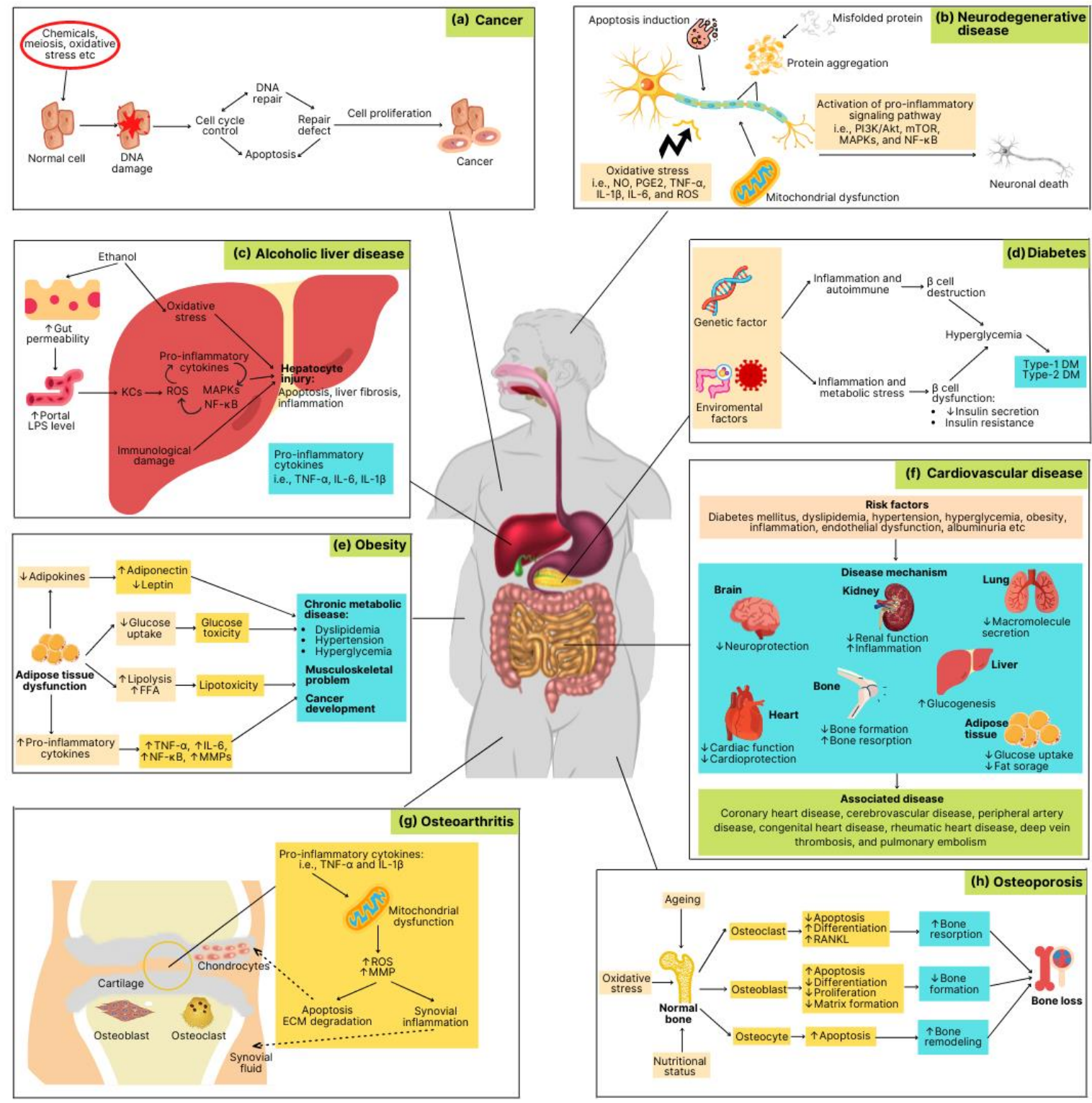

Figure 4. Mechanisms of chronic diseases, including cancer (a), neurodegenerative disease (b), alcoholic liver disease (c), diabetes (d), obesity (e), cardiovascular disease (f), osteoarthritis (g) and osteoporosis (h).

\subsection{Cancer}

The mechanism of cancer cell formation and proliferation is shown in Figure 4a. Numerous studies on the effects of seaweed extracts against breast cancer have been reported. Sargassum hemiphyllum fucoidan inhibited the viability of MCF-7 and MDA-MB-231 cell lines by modulating the miR-29c/ADAM12 and miR-17-5p/PTEN axes [72]. Laurencia papillosa [117] and Sargassum sp. [118] showed significant inhibition of viability of the MCF-7 cell line. A high level of inhibition of the MDA-MB-231 cell line was also observed following treatment with Bifurcaria bifurcata [119] and Ulva fasciata by downregulating the EGFR/PI3K/Akt pathway [120]. Eucheuma cottonii suppressed the growth of tumor cells in rats inoculated with breast-cancer tumors in in vivo experiment [118]. Other in vivo studies reported that Wistar rats administered with $50 \mathrm{mg} / \mathrm{kg}$ body weight orally, daily for 10 weeks, suppressed breast carcinogenesis [121]. Studies of the effects of seaweedderived compounds on cancer which were conducted in vitro and in vivo are summarized in Table 1. 
Table 1. The effects of seaweed-derived compounds on cancer.

\begin{tabular}{|c|c|c|c|c|}
\hline Algal Source & Constituent & Study Type & Biological Effects & Ref. \\
\hline \multicolumn{5}{|c|}{ Brown seaweed } \\
\hline Sargassum hemiphyllum & Fucoidan & In vitro & $\begin{array}{l}\text { Inhibited the progression of MCF-7 } \\
\text { and MDA-MB-231 cell lines }\end{array}$ & [72] \\
\hline Bifurcaria bifurcata & Diterpenes & In vitro & $\begin{array}{l}\text { Inhibited the growth of MDA-MB-231 } \\
\text { cell line }\left(\mathrm{IC}_{50}=11.6 \text { to } 32.0 \mu \mathrm{g} / \mathrm{mL}\right)\end{array}$ & [119] \\
\hline Sargassum sp. & Ethanol extract & In vitro & $\begin{array}{l}\text { Inhibited the growth of MCF-7 cell } \\
\text { line }\left(\mathrm{IC}_{50}=250 \mu \mathrm{g} / \mathrm{mL}\right)\end{array}$ & [31] \\
\hline Hizikia fusiforme & $\begin{array}{c}\text { Sulfated } \\
\text { polysaccharide }\end{array}$ & In vitro and in vivo & $\begin{array}{l}\text { Inhibited the growth of human } \\
\text { bladder cancer EJ cell line }\end{array}$ & [122] \\
\hline Laminaria japonica & Laminarin & In vitro and in vivo & $\begin{array}{l}\text { Inhibited hepatocellular carcinoma } \\
\text { (HCC) cell proliferation }\end{array}$ & [123] \\
\hline Fucus vesiculosus & Fucoidan & In vitro & Inhibited HT-29 cell prolifeation & [124] \\
\hline \multicolumn{5}{|c|}{ Red Seaweed } \\
\hline Laurencia papillosa & $\begin{array}{c}\text { Sulfated } \\
\text { polysaccharides }\end{array}$ & In vitro & Inhibited MCF-7 cell viability & [117] \\
\hline Eucheuma cottonii & Ethanol extract & In vivo & Inhibited the growth of breast tumor & [118] \\
\hline Gigartina pistillata & Carrageenans & In vitro & $\begin{array}{l}\text { Inhibited colorectal cancer stem cell } \\
\text { viability }\left(\mathrm{IC}_{50}=1 \mu \mathrm{g} / \mathrm{mL}\right)\end{array}$ & [125] \\
\hline Champia feldmannii & $\begin{array}{l}\text { Sulfated } \\
\text { polysaccharides }\end{array}$ & In vitro and in vivo & $\begin{array}{c}\text { Inhibited sarcoma } 180 \text { ascites tumor } \\
\text { cell growth }\end{array}$ & [126] \\
\hline Gracilaria fisher & Sulfated galactans & In vitro & Restored migration of CCA cells & [127] \\
\hline \multicolumn{5}{|c|}{ Green Seaweed } \\
\hline Ulva fasciata & Guai-2-en-10a-ol & In vitro & $\begin{array}{l}\text { Inhibited the growth of } \\
\text { MDA-MB-231 cell line }\end{array}$ & [120] \\
\hline Ulva lactuca & Ulvan & In vitro and in vivo & $\begin{array}{l}\text { Inhibited MCF-7 cell viability } \\
\text { Inhibited breast carcinogenesis }\end{array}$ & [121] \\
\hline Ulva lactuca & $\begin{array}{l}\text { Aqueous-ethanolic } \\
\text { extract }\end{array}$ & In vivo & $\begin{array}{l}\text { Inhibited benzo(a)pyrene-induced } \\
\text { toxicity in mice }\end{array}$ & [128] \\
\hline Gayralia oxysperma & $\begin{array}{c}\text { Sulfated } \\
\text { heterorhamnans }\end{array}$ & In vitro & $\begin{array}{l}\text { Inhibited the growth of } \\
\text { U87MG cell line }\end{array}$ & [129] \\
\hline
\end{tabular}

Carrageenan extract from Gigartina pistillata inhibits cell growth in colorectal cancer stem cells with an $\mathrm{IC}_{50}$ value of $1 \mu \mathrm{g} / \mathrm{mL}$ [125]. Moreover, Hizikia fusiforme inhibited EJ tumor growth both in vivo and in vitro through G1-phase cell cycle arrest by downregulating cyclins and cyclin-dependent kinases (CDKs), as well as by inhibiting the expression of MMP-9 by downregulating NF- $\mathrm{kB}, \mathrm{AP}-1$, and Sp-1 [122]. In addition, seaweed extract also exhibited potent anticancer activity against hepatocellular carcinoma (HCC) cell lines [123], the U87MG cell line [129], and sarcoma 180 ascites tumor cells both in vitro and in vivo [126]. Furthermore, the inhibition of HT-29 cell proliferation by fucoidan may be due to the downregulation of IGF-IR signaling by the main IRS-1/PI3K/AKT pathway.

\subsection{Neurodegenerative Disease}

Neurodegenerative diseases are age-related chronic and progressive loss of neurons, such as Alzheimer's disease, Parkinson's disease, amyotrophic lateral sclerosis, Huntington's disease, multiple sclerosis, cerebral ischemia, and traumatic brain injury [130,131]. The major cellular and molecular events that cause neurodegeneration are oxidative stress, misfolded proteins, impaired mitochondrial function, apoptosis induction, proteostasis impairment, and neuroinflammation [132]. The mechanism of neurodegenerative disease is shown in Figure $4 \mathrm{~b}$. Studies of the effects of seaweed-derived compounds on neurodegenerative diseases are summarized in Table 2. 
Table 2. The effects of seaweed-derived compounds on neurogenerative diseases.

\begin{tabular}{|c|c|c|c|c|}
\hline Algal Source & $\begin{array}{l}\text { Compound of Interest } \\
\text { and Fraction }\end{array}$ & Study Type & Biological Effects & Ref. \\
\hline \multicolumn{5}{|c|}{ Brown seaweed (Phaeophyta) } \\
\hline Bifurcaria bifurcata & Phenolic fraction & In vitro & $\begin{array}{l}\text { Prevented mitochondrial potential changes, } \\
\text { decreased } \mathrm{H}_{2} \mathrm{O}_{2} \text { production, and inhibited } \\
\text { Caspase- } 3 \text { activity }\end{array}$ & [116] \\
\hline Undaria pinnatifida & Ethanol extract & In vitro & $\begin{array}{c}\text { Decreased ER stress via upregulating } \\
\text { Akt/mTOR signaling pathway }\end{array}$ & [133] \\
\hline Undaria pinnatifida & $\begin{array}{l}\text { Fucoxanthin and } \\
\text { fucosterol }\end{array}$ & In vitro and in silico & $\begin{array}{c}\text { Moderate inhibition for fucoxanthin and } \\
\text { inactive for fucosterol on two isoenzymes } \\
\text { Fucoxanthin as potential dopamine D3/D4 } \\
\text { agonist }\end{array}$ & [106] \\
\hline Undaria pinnatifida & $\begin{array}{l}\text { Fucosterol and } \\
\text { fucoxanthin }\end{array}$ & In vitro & Inhibitory effects on BACE1 & [134] \\
\hline Ishige foliacea & Ethanol extract & In vitro and in vivo & $\begin{array}{c}\text { Decreased } A \beta \text { accumulation } \\
\text { Inhibited AChE, BACE1, and memory } \\
\text { deficit }\end{array}$ & [135] \\
\hline Sargassum horneri & Fucoxanthin & In vitro & $\begin{array}{l}\text { Decreased } \mathrm{H}_{2} \mathrm{O}_{2} \text {-induced neurotoxicity by } \\
\text { upregulating the PI3K/Akt cascade and } \\
\text { inhibiting the ERK pathway }\end{array}$ & [107] \\
\hline Ecklonia cava & Polyphenol & In vitro and in vivo & $\begin{array}{l}\text { Reduced } \mathrm{Ca}^{2+}-\text { mediated neurotoxicity on } \\
\text { ischemic rats }\end{array}$ & [136] \\
\hline Ecklonia cava & $\begin{array}{c}\text { Dieckol and } \\
\text { phlorofucofuroeckol }\end{array}$ & In vivo & $\begin{array}{c}\text { Increased acetylcholine and reduced } \\
\text { anticholinesterase activities }\end{array}$ & [98] \\
\hline Ecklonia cava & Butanol & In vitro and in vivo & Reduced A $\beta$ secretion and cell death & [137] \\
\hline Ecklonia cava & Phlorotannin & In vitro & $\begin{array}{l}\text { Regulated the expression and activity of } \\
\text { alpha- and gamma-secretase } \\
\text { Reduced } \mathrm{A} \beta \text { production }\end{array}$ & [138] \\
\hline Eisenia bicyclis & Eckol and dieckol & In silico & $\begin{array}{c}\text { Inhibited } h \mathrm{MAOs} \text { by its higher binding } \\
\text { affinity }\end{array}$ & [97] \\
\hline Ishige okamurae & $\begin{array}{l}\text { Fresh seaweed and } \\
\text { ethanolic extract }\end{array}$ & In vitro and vivo & $\begin{array}{c}\text { Reduced } \mathrm{A} \beta_{25-35} \text {-induced phosphorylation } \\
\text { by downregulating ERK, p38 MAPK, and } \\
\text { JNK pathway }\end{array}$ & [139] \\
\hline Ecklonia maxima & Phenolic extract & In vitro & $\begin{array}{c}\text { Inhibited acetylcholinesterase and } \\
\text { butyrylcholinesterase activities }\end{array}$ & [140] \\
\hline Sargassum fusiforme & Polysaccharide & In vivo & $\begin{array}{l}\text { Reduced memory deficiencies and } \\
\text { improved cognitive abilities of rats }\end{array}$ & [28] \\
\hline Ecklonia stolonifera & $\begin{array}{l}\text { Fucosterol and } \\
\text { fucoxanthin }\end{array}$ & In vitro & Inhibitory effects on BACE1 & [134] \\
\hline \multicolumn{5}{|c|}{ Red seaweed (Rhodophyta) } \\
\hline Gracilaria cornea & Sulfated agaran & In vivo & $\begin{array}{l}\text { Reduced oxidative stress } \\
\text { Recovered behavioral activity and weight } \\
\text { gain of rats to normal }\end{array}$ & [141] \\
\hline Gracilaria beckeri & Phenolic extract & In vitro & $\begin{array}{c}\text { Inhibited acetylcholinesterase and } \\
\text { butyrylcholinesterase activities }\end{array}$ & [140] \\
\hline Gelidium pristoides & Phenolic extract & In vitro & $\begin{array}{l}\text { Inhibited acetylcholinesterase and } \\
\text { butyrylcholinesterase activities }\end{array}$ & [140] \\
\hline $\begin{array}{l}\text { Gelidium amansii (formerly } \\
\quad \text { Gelidium elegans) }\end{array}$ & Ethanol extracts & In vitro & $\begin{array}{c}\text { Promoted the initial neuronal } \\
\text { differentiation }\end{array}$ & [142] \\
\hline \multicolumn{5}{|c|}{ Green Seaweed (Chlorophyta) } \\
\hline Caulerpa racemosa & $\begin{array}{l}\text { Racemocin } \mathrm{A} \text { and } \\
\text { racemocin } \mathrm{B}\end{array}$ & In vitro & Increased cell viability of SH-SY5Y cells & [114] \\
\hline Ulva rigida & Phenolic extract & In vitro & $\begin{array}{l}\text { Inhibited acetylcholinesterase and } \\
\text { butyrylcholinesterase activities }\end{array}$ & [140] \\
\hline
\end{tabular}

The activation of microglia-a macrophage cell production in the central nervous system (CNS) due to the excessive production of inflammatory mediators such as nitric oxide (NO), prostaglandin E2 (PGE2), and pro-inflammatory cytokines, e.g., tumor necrosis factor- $\alpha$ (TNF- $\alpha$ ), interleukin (IL)- $1 \beta$, IL-6, and reactive oxygen species (ROS) - can cause chronic neurodegeneration [130,143]. Myagropsis myagroides sargachromenol reduced inflammation in lipopolysaccharide (LPS)-stimulated microglia by downregulating the I $\mathrm{B}-\alpha / \mathrm{NF}-\mathrm{kB}$ and ERK/JNK pathways [130]. One of the factors causing misfolded proteins that is associated with neurodegenerative diseases is increased endoplasmic reticulum (ER) 
stress. Ethanol extract from Undaria pinnatifida was reported to decrease endoplasmic reticulum (ER) voltage through the Akt/mTOR signaling pathway [133]. Fucoxanthin extract of Sargassum horneri showed neurodegenerative effects by decreasing $\mathrm{H}_{2} \mathrm{O}_{2}$-induced neurotoxicity via upregulating of the PI3K/Akt cascade and inhibition of the ERK pathway [107]. Bisindole alkaloids, namely racemocin A and racemocin B from Caulerpa racemose, reduced the $\mathrm{A} \beta_{25-35}$-induced SH-SY5Y cell (neuroblast from neural tissue) damage by increasing cell viability of $5.5 \%$ and $14.6 \%$ for racemocin A and racemocin B, respectively [114]. Fucoxanthin may rescue cerebral ischemic/reperfusion injury from nerve inflammation and oxidative stress by promoting the Nrf2/HO-1 signaling pathway in rats [21]. Reducing $\mathrm{Ca}^{2+}$-mediated neurotoxicity could protect rats with cerebral ischemic/reperfusion injury from nerve inflammation and oxidative stress [136].

Alzheimer's disease is a type of dementia that causes a global, progressive, and irreversible deterioration of various cognitive functions (memory, attention, concentration, language, and thinking, among others) [144]. The main cause of Alzheimer's disease is the dysregulation of $\beta$-amyloid $(\mathrm{A} \beta)$ levels, which induces neuronal death via multiple mechanisms, including oxidative stress, excitotoxicity, apoptosis, and inflammation [145]. According to Kim et al. [135], Ishige foliacea may decrease A $\beta$ accumulation, thus inhibiting AChE and BACE1 [134], and suppress memory deficits by enhancing the BDNF-TrkB-ERK signaling pathway in the hippocampus. Butanol extracts from Ecklonia cava have anti-A $\beta$ effects on $A \beta$-related pathogenesis, including amyloidogenic processing, $A \beta$ oligomerization, $A \beta$ fibrillization, and $A \beta$-induced neuronal death [137]. By downregulating the ERK, p38 MAPK, and JNK pathways, compounds isolated from Ishige okamurae reduced $A \beta_{25-35}$-induced phosphorylation both in vitro and in vivo [139]. Phenolic compounds from Gracilaria beckeri, Ecklonia maxima, Gelidium pristoides, and Ulva rigida, such as phloroglucinol, catechin, and epicatechin 3-glucoside, significantly reduced anti-acetylcholinesterase and butyrylcholinesterase activities [140].

Parkinson's disease is a prevalent neurological disease affecting the movement of the elderly. It is characterized by the formation of Lewy bodies, the death of dopaminergic neurons in the substantia nigra pars compacta (SNpc), and dopamine depletion (DA) $[116,146]$. During aging, the concentration of iron in the brain can change, resulting in metabolic stress $[147,148]$. The neuroprotective activity of Bifurcaria bifurcata fractions suggested that two major diterpenes (eleganolone and eleganonal) have potential for Parkinson's disease management because of their iron-reducing activities [116]. Silva et al. [149] reported that among the three macroalgae tested, Saccorhiza polyschides exhibited the highest potential as a therapeutic agent against AD-induced toxicity, exhibiting anti-apoptotic effects associated with mitochondrial protection and caspase-3 inhibition in a model of Parkinson's disease. Two extracts, Undaria pinnatifida and fucoxanthin, showed moderate inhibition and were inactive against $h \mathrm{MAO}-\mathrm{A}$ and $h \mathrm{MAO}-\mathrm{B}$ [135]. These results suggest that fucoxanthin may be beneficial for Parkinson's disease due to its ability as a potent dopamine D3/D4 agonist agent. An in vivo study reported that rats fed sulfated agaran exhibited great neuroprotection due to its ability to reduce oxidative stress, and showed recovery of behavioral activity and improved weight gain [141].

Based on previous research, extracts of phlorotannins and their derivatives from brown seaweed demonstrate neuroprotective activity. Ecklonia cava phlorotannin downregulates the expression and activity of alpha- and gamma-secretase [138], while its derivatives dieckol and phlorofucofuroeckol increase acetylcholine and reduce anticholinesterase activities [98], which lead to a reduction in A $\beta$ production. In addition, dieckol and eckol from Eisenia bicyclis showed a higher binding affinity for hMAOs by hydrogen bonding and hydrophobic interactions compared to $h \mathrm{MAO}-\mathrm{A}$ and $h \mathrm{MAO}-\mathrm{B}$ [97].

\subsection{Liver Disease}

The liver is the main metabolic organ for the detoxification of drugs and xenobiotics, crucial to combatting oxidative-stress-inducing agents that circulate in the blood [150]. However, excessive alcohol intake can cause liver diseases, including alcoholic liver disease 
(ALD) and nonalcoholic fatty liver disease (NAFLD). The mechanism of alcocholic liver disease is shown in Figure 4c. Several studies on bioactive compounds for liver disease management have been conducted (Table 3).

Table 3. The effects of seaweed-derived compounds on liver disease.

\begin{tabular}{|c|c|c|c|c|}
\hline Algal Source & Constituents & Study Type & Biological Effects & Ref. \\
\hline \multicolumn{5}{|c|}{ Brown seaweed (Phaeophyta) } \\
\hline Ecklonia cava & 7-phloro-eckol & In vitro & $\begin{array}{l}\text { Reduced alcohol-induced oxidative } \\
\text { stress injury }\end{array}$ & [100] \\
\hline Sargassum fluitans & Ethanol extract & In vivo & $\begin{array}{l}\text { Reduced the level of } \mathrm{APAP}^{-} \text {and } \\
\mathrm{CCl}_{4}^{-} \text {induced liver damage }\end{array}$ & [32] \\
\hline Sargassum ilicifolium & Ethanol extract & In vivo & $\begin{array}{c}\text { Showed nephroprotective and } \\
\text { hepatoprotective effects }\end{array}$ & [151] \\
\hline Turbinaria decurrens & Fucoidan & In vivo & $\begin{array}{l}\text { Improved antioxidant status and } \\
\text { reduced liver injury }\end{array}$ & [73] \\
\hline Myagropsis myagroides & Aqueous extracts & In vivo & $\begin{array}{c}\text { Reduced the } \mathrm{CCl}_{4}-\text { induced acute } \\
\text { elevation in the levels of GPT and } \\
\text { GOT in rats }\end{array}$ & [152] \\
\hline $\begin{array}{c}\text { Sargassum } \\
\text { henslowianum }\end{array}$ & Aqueous extracts & In vivo & $\begin{array}{c}\text { Reduced the } \mathrm{CCl}_{4}{ }^{-} \text {induced acute } \\
\text { elevation in the levels of GPT and } \\
\text { GOT in rats }\end{array}$ & [152] \\
\hline Sargassum siliquastrum & Aqueous extracts & In vivo & $\begin{array}{c}\text { Reduced the } \mathrm{CCl}_{4}{ }^{-} \text {induced acute } \\
\text { elevation in the levels of GPT and } \\
\text { GOT in rats }\end{array}$ & [152] \\
\hline Fucus vesiculosus & Fucoidan & In vivo & $\begin{array}{l}\text { Ameliorated thioacetamide } \\
\text { (TAA)-induced liver injury }\end{array}$ & [153] \\
\hline Fucus vesiculosus & Phytocomplex & In vitro and in vivo & $\begin{array}{l}\text { Reduced both the postprandial } \\
\text { glycemic peak and the blood glucose } \\
\text { curve (AUC) }\end{array}$ & [154] \\
\hline Ascophyllum nodosum & Phytocomplex & In vitro and in vivo & $\begin{array}{l}\text { Inhibited in carbohydrate digestion } \\
\text { Reduced both the postprandial } \\
\text { glycemic peak and the blood glucose } \\
\text { curve (AUC) }\end{array}$ & [154] \\
\hline Cladosiphon okamuranus & Fucoidan & In vivo & $\begin{array}{c}\text { Inhibited in carbohydrate digestion } \\
\text { Showed isoproterenol-induced } \\
\text { myocardial infarction }\end{array}$ & [155] \\
\hline Sargassum thunbergii & $\begin{array}{c}\text { Indole-4- } \\
\text { carboxaldehyde }\end{array}$ & In vitro & $\begin{array}{l}\text { Reduced pro-inflammatory mediator, } \\
\text { i.e., methylglyoxal (MGO) and } \\
\text { advanced glycation end-product } \\
\text { (AGE) formation }\end{array}$ & [156] \\
\hline \multicolumn{5}{|c|}{ Red Seaweed (Rhodophyta) } \\
\hline Halymenia porphyroides & Ethanol extract & In vivo & $\begin{array}{l}\text { Showed nephroprotective and } \\
\text { hepatoprotective effects }\end{array}$ & [151] \\
\hline Gracilaria lemaneiformis & Oligosaccharides & In vivo & Exerted antioxidant defense system & [157] \\
\hline \multicolumn{5}{|c|}{ Green Seaweed (Chlorophyta) } \\
\hline Ulva lactuca & $\begin{array}{c}\text { Sulfated } \\
\text { polysaccharide }\end{array}$ & In vivo & $\begin{array}{l}\text { Reduced } \mathrm{D}^{-} \text {-Gal-induced DNA damage } \\
\text { and necrosis level in rats }\end{array}$ & [8] \\
\hline
\end{tabular}

Recent studies have reported that Sargassum ilicifolium showed better inhibition of nephroprotective and hepatoprotective effects than Halymenia porphyroides in the liver and kidney of rats after damage by administration of acetaminophen or cisplatin [151]. Hepatoprotection has been reported with the administration of Turbinaria decurrens fucoidan, which ameliorates antioxidant status and decreases lipid peroxidation marker levels [73]. Administration of $50 \mathrm{mg} / \mathrm{kg}$ Sargassum fluitans ethanol extract reduced the levels of $\mathrm{APAP}^{-}$and $\mathrm{CCl}_{4}{ }^{-}$in liver damage models through the inhibition of inflammation and fibrosis in liver tissue [32]. This result is in accordance with the research on the hepatoprotective effects of Myagropsis myagroides, Sargassum henslowianum, and Sargassum 
siliquastrum [152]. Fucus vesiculosus fucoidan may exert thioacetamide (TAA)-induced liver injury by downregulating pro-inflammatory cytokines [153]. Moreover, fucoidan from Cladosiphon okamuranus showed hepatoprotective effects by improving the antioxidant defense system and reducing ROS [155].

The ALD symptoms, such as fatty liver disease and hepatitis, can progress to steatohepatitis, liver fibrosis, cirrhosis, and the most severe form of liver cancer [158]. 7-phloro-eckol isolated from Ecklonia cava showed an inhibitory effect on ALD by reducing alcohol-induced oxidative stress injury in HepG2/CYP2E1 cells [100]. Meanwhile, other seaweeds such as Ulva lactuca can reduce D-Gal-induced DNA damage and necrosis levels in rats [8]. NAFLD refers to a group of liver disorders that range from fat accumulation in the liver (steatosis) to nonalcoholic steatohepatitis (necrosis and inflammation), with some cases progressing to fibrosis, cirrhosis, and liver failure [159]. One of the progressive stages of NAFLD is called nonalcoholic steatohepatitis (NASH), which is associated with hepatocyte injury, excessive oxidative stress, and chronic inflammation in the fatty liver, and can progress to more serious liver diseases such as cirrhosis and hepatocellular carcinoma $[160,161]$. The phytocomplex of Fucus vesiculosus and Ascophyllum nodosum suggests a reduction in the postprandial glycemic peak and the blood glucose curve (AUC), and an inhibitory effect on carbohydrate digestion [154].

\subsection{Diabetes}

In recent years, diabetes has become a major health problem worldwide, particularly among youth [162]. Diabetes is a metabolic disorder characterized by insufficient insulin secretion and improper insulin utilization [163]. It is divided into two types: insulindependent diabetes mellitus (type 1 diabetes) and non-insulin-dependent diabetes mellitus (type 2 diabetes) [101]. Previous studies have shown that seaweed, which is high in bioactive compounds, has anti-diabetic properties (Table 4 ).

Table 4. The effects of seaweed-derived compounds on diabetes.

\begin{tabular}{|c|c|c|c|c|}
\hline Algal Source & Constituent & Study Type & Biological Effects & Ref. \\
\hline \multicolumn{5}{|c|}{ Brown Seaweed (Phaeophyta) } \\
\hline Ecklonia cava & AG-dieckol & In vivo & Reduced total glucose and lipid & [101] \\
\hline Ecklonia cava & Dieckol & In vivo & $\begin{array}{l}\text { Reduced blood glucose level, serum } \\
\text { insulin level and body weight } \\
\text { Inhibited the activation of high }\end{array}$ & [102] \\
\hline Ecklonia cava & Polyphenol & In vivo & $\begin{array}{l}\text { glucose-induced hepatic stellate cells } \\
\text { (HSCs) }\end{array}$ & [164] \\
\hline Sargassum hemiphyllum & $\begin{array}{l}\text { Fucoidan and } \\
\text { fucoxanthin }\end{array}$ & In vivo & $\begin{array}{c}\text { Reduced urinary sugar } \\
\text { Reduced total glucose and lipid } \\
\text { Inhibited pro-inflammatory mediators }\end{array}$ & [165] \\
\hline Sargassum hemiphyllum & Oligo-fucoidan & In vitro and in vivo & $\begin{array}{c}\text { Inhibitory effects on diabetes-evoked } \\
\text { renal fibrosis }\end{array}$ & [166] \\
\hline Padina arborescens & Methanolic extract & In vivo & $\begin{array}{c}\text { Ameliorated hyperglycemia and } \\
\text { dyslipidemia }\end{array}$ & [167] \\
\hline Ascophyllum nodosum & $\begin{array}{l}\text { Carbohydrate- and } \\
\text { polyphenolic-enriched } \\
\text { extracts }\end{array}$ & In vitro & $\begin{array}{l}\text { Inhibited } \alpha \text {-glucosidase } \\
\text { Inhibition of sucrase } \\
\left(\mathrm{IC}_{50}=0.83 \mathrm{mg} / \mathrm{mL}\right)\end{array}$ & [168] \\
\hline
\end{tabular}


Table 4. Cont.

\begin{tabular}{|c|c|c|c|c|}
\hline Algal Source & Constituent & Study Type & Biological Effects & Ref. \\
\hline Ascophyllum nodosum & Fucoidan & In vitro & $\begin{array}{c}\text { Inhibited } \alpha \text {-glucosidase } \\
\left(\mathrm{IC}_{50}=0.013-0.047 \mathrm{mg} / \mathrm{mL}\right) \\
\text { Inhibited } \alpha \text {-amylase } \\
\left(\mathrm{IC}_{50}=0.12-4.64 \mathrm{mg} / \mathrm{mL}\right)\end{array}$ & [169] \\
\hline Fucus vesiculosus & $\begin{array}{l}\text { Carbohydrate- and } \\
\text { polyphenolic-enriched } \\
\text { extracts }\end{array}$ & In vitro & Inhibited $\alpha$-glucosidase & [168] \\
\hline Fucus vesiculosus & Fucoidan & In vitro & $\begin{array}{l}\text { Inhibited } \alpha \text {-glucosidase } \\
\left(\mathrm{IC}_{50}=0.049 \mathrm{mg} / \mathrm{mL}\right)\end{array}$ & [169] \\
\hline Undaria pinnatifida & $\begin{array}{l}\text { Carbohydrate- and } \\
\text { polyphenolic-enriched } \\
\text { extracts }\end{array}$ & In vitro & Inhibited $\alpha$-glucosidase & [168] \\
\hline Ishige foliacea & Octaphlorethol A & In vitro & $\begin{array}{l}\text { Upregulated transporter } 4 \text { (Glut4) } \\
\text { translocation }\end{array}$ & [170] \\
\hline Ishige foliacea & Octaphlorethol A & In vivo & $\begin{array}{c}\text { Downregulated hepatic } \\
\text { gluconeogenesis }\end{array}$ & [171] \\
\hline Sargassum polycystum & $\begin{array}{l}\text { Ethanolic and aqueous } \\
\text { extracts }\end{array}$ & In vivo & $\begin{array}{c}\text { Ameliorated kidney, liver, and } \\
\text { pancreas damage }\end{array}$ & [172] \\
\hline Scagassum & Polysaccharide fraction & In vivo & $\begin{array}{l}\text { Regulated glucose, triglyceride (TG), } \\
\text { and total cholesterol } \\
\text { Ameliorated liver and kidney damage }\end{array}$ & [173] \\
\hline Sargassum fusiforme & Polysaccharide fraction & In vivo & $\begin{array}{l}\text { Regulated glucose, triglyceride (TG), } \\
\text { and total cholesterol }\end{array}$ & [173] \\
\hline $\begin{array}{c}\text { Macrocystis } \\
\text { pyrifera }\end{array}$ & Polysaccharide fraction & In vivo & $\begin{array}{l}\text { Regulated glucose, triglyceride (TG), } \\
\text { and total cholesterol } \\
\text { Ameliorated liver and kidney damage }\end{array}$ & [173] \\
\hline Laminaria japonica & Fucoxanthin & In vitro and in vivo & $\begin{array}{c}\text { Reduced NO production and ROS } \\
\text { level } \\
\text { Increased insulin resistance } \\
\text { Ameliorated improved } \\
\text { spermatogenesis and male } \\
\text { reproductive function }\end{array}$ & [104] \\
\hline Ecklonia stolonifera & Phlorotannin & In vitro & $\begin{array}{c}\text { Inhibitory effects on PTP1B and } \\
\alpha \text {-glucosidase }\end{array}$ & [174] \\
\hline Ecklonia stolonifera & Fucosterol & In vitro & $\begin{array}{c}\text { Moderate inhibitory effects on RLAR, } \\
\text { HRAR, and PTP1B }\end{array}$ & [10] \\
\hline Eisenia bicyclis & Phlorotannin & In vitro & $\begin{array}{c}\text { Inhibitory effects on PTP1B and } \\
\alpha \text {-glucosidase }\end{array}$ & [174] \\
\hline Eisenia bicyclis & Fucosterol & In vitro & $\begin{array}{c}\text { Moderate inhibitory effects on RLAR, } \\
\text { HRAR, and PTP1B }\end{array}$ & [10] \\
\hline \multicolumn{5}{|c|}{ Red Seaweed (Rhodophyta) } \\
\hline Bryothamnion seaforthii & Lectin & In vivo & $\begin{array}{l}\text { Exerted hypoglycemic and } \\
\text { hypolipidemic effects } \\
\text { Reduce insulin resistance and } \\
\text { improved pancreatic } \beta \text {-cell function }\end{array}$ & [111] \\
\hline \multicolumn{5}{|c|}{ Green Seaweed (Chlorophyta) } \\
\hline Enteromorpha prolifera & Flavonoids & In vitro & $\begin{array}{l}\text { Reduced inflammation in liver and } \\
\text { kidney } \\
\text { Regulated insulin signaling pathway } \\
\text { Enriched the abundance of gut } \\
\text { microbiota } \\
\text { Regulated gene expression }\end{array}$ & {$[14]$} \\
\hline Enteromorpha prolifera & Polyphenols & In vivo & $\begin{array}{l}\text { Enriched the abundance of gut } \\
\text { microbiota }\end{array}$ & [9] \\
\hline Ulva rigida & Ethanolic extract & In vitro & $\begin{array}{c}\text { Ameliorated carbohydrate } \\
\text { metabolism, hyperlipidemia, and } \\
\text { oxidative stress }\end{array}$ & [175] \\
\hline
\end{tabular}


Type 2 diabetes is the most common type of diabetes, and its prevalence is increasing significantly worldwide. The mechanism of diabetes is shown in Figure 4d. Hyperglycemia plays an important role in the development of type 2 diabetes and complications associated with the disease, such as microvascular and macrovascular diseases [176]. Several studies have been conducted that suggest extracts from seaweeds could combat diabetes. For instance, flavonoids present in Enteromorpha prolifera exhibited hypoglycemic effects by upregulating IRS1/PI3K/AKT and downregulating the JNK1/2 insulin pathway in the liver [14]. This study also reported that treatment in type 2 diabetic mice enriched the abundance of gut microbiota, such as Turicibacter and Alisties [9]. Meanwhile, phlorotannin (dieckol) of Ecklonia cava, fucoidan, and fucoxanthin of Sargassum hemiphyllum reduced total glucose, lipid, serum insulin levels, and body weight in vivo [101,102,165]. Furthermore, polyphenols extracted from Ecklonia cava also inhibited the activation of high glucose-induced hepatic stellate cells (HSCs) by downregulating ROS and/or GSH and inhibiting TGF- $\beta$ secretion [164]. In addition, Padina arborescens may ameliorate hyperglycemia and dyslipidemia in in C57BL/KsJ-db/db mice. A novel phenolic compound from Ishige foliacea, octaphlorethol A, was tested in vitro, and may increase glucose transporter 4 (Glut4) translocation, which is mediated by PI3K/Akt and AMPK activation [170] Additionally, octaphlorethol A was found to downregulate hepatic gluconeogenesis in vivo by inhibiting G6Pase and PEPCK activity [171]. Polysaccharide fractions from Scagassum, Sargassum fusiforme, and Macrocystis pyrifera may regulate glucose, triglyceride (TG), and total cholesterol, subsequently ameliorating liver and kidney damage [173].

Many seaweeds also exhibit inhibitory effects on $\alpha$-glucosidase and $\alpha$-amylase, such as Ascophyllum nodosum, Fucus vesiculosus, and Undaria pinnatifida [168,169]. Bioactive compounds from Ecklonia stolonifera and Eisenia bicyclis, including phlorotannin, showed inhibitory effects on protein tyrosine phosphatase 1 B (PTP1B) and $\alpha$-glucosidase [174], whereas phlorotannin showed moderate inhibitory effects on rat lens aldose reductase (RLAR), human recombinant aldose reductase (HRAR), and PTP1B [10]. Other studies have demonstrated that lectin isolated from Bryothamnion seaforthii exerts hypoglycemic and hypolipidemic effects, reduces insulin resistance, and improves pancreatic $\beta$-cell function in rats with streptozotocin (STZ)-induced diabetes [111]. In the same animal model, Ulva rigida showed inhibition of carbohydrate metabolism, hyperlipidemia, and oxidative stress [175].

\subsection{Obesity}

Recently, the anti-obesity activity of seaweed has received considerable attention (Table 5). Obesity is generally considered a risk factor for a number of chronic metabolic diseases, dyslipidemia, hypertension, and hyperglycemia [177]. Obesity can also lead to musculoskeletal problems and an increased risk of cancers, such as colorectal, breast, and endometrial cancers [178].

Table 5. The effects of seaweed-derived compounds on obesity.

\begin{tabular}{|c|c|c|c|c|}
\hline Algal Source & Constituents & Study Type & Biological Effects & Ref. \\
\hline \multicolumn{5}{|c|}{ Brown seaweed (Phaeophyta) } \\
\hline Sargassum miyabei & Crude extract & In vitro & $\begin{array}{c}\text { Reduced lipid accumulation and } \\
\text { differentiation } \\
\text { Inhibited adipogenic and lipogenic gene } \\
\text { expression }\end{array}$ & [179] \\
\hline Saccorhiza polyschides & Polysaccharide & In vivo & $\begin{array}{l}\text { Regulated intestinal and systemic glucose } \\
\text { metabolism } \\
\text { Inhibition of } \alpha \text {-amylase activity }\end{array}$ & [180] \\
\hline
\end{tabular}


Table 5. Cont.

\begin{tabular}{|c|c|c|c|c|}
\hline Algal Source & Constituents & Study Type & Biological Effects & Ref. \\
\hline Fucus vesisulosus & Fucoidan & In vitro & $\begin{array}{l}\text { Inhibited lipid accumulation } \\
\text { Inhibited adipogenic and lipogenic genes }\end{array}$ & [181] \\
\hline Petalonia binghamiae & Water-soluble extract & In vivo & $\begin{array}{l}\text { expression } \\
\text { Reduced body weight }\end{array}$ & [182] \\
\hline Ecklonia stolonifera & Fucosterol & In vitro & $\begin{array}{l}\text { Inhibited adipogenic and lipogenic gene } \\
\text { expression }\end{array}$ & [183] \\
\hline Ecklonia stolonifera & Fucosterol & In vitro & $\begin{array}{l}\text { Inhibited adipogenesis via FoxO1 } \\
\text { pathway modulation }\end{array}$ & [184] \\
\hline Ecklonia cava & Phlorotannin & In vitro & Inhibited adipogenic expression & [185] \\
\hline Ecklonia cava & Polyphenol Extract & In vivo & Inhibited lipogenesis & [186] \\
\hline Undaria pinnatifida & Fucoxanthin & In vivo & Inhibited lipogenesis & [105] \\
\hline Eisenia bicyclis & 6,6'-Bieckol & In vitro & Inhibited adipogenesis & [96] \\
\hline \multicolumn{5}{|c|}{ Red seaweed (Rhodophyta) } \\
\hline $\begin{array}{l}\text { Gelidium amansii } \\
\text { (formerly G. elegans) }\end{array}$ & $\begin{array}{l}\text { Polysaccharide-rich } \\
\text { extract }\end{array}$ & In vivo & $\begin{array}{c}\text { Decreased triglyceride and total } \\
\text { cholesterol levels } \\
\text { Decreased body and adipose tissue } \\
\text { weights }\end{array}$ & [43] \\
\hline $\begin{array}{l}\text { Gelidium amansii } \\
\text { (formerly G. elegans) }\end{array}$ & Ethanolic extract & In vivo & Inhibited adipogenesis & [187] \\
\hline Plocamium telfairiae & Ethanolic extract & In vitro and in vivo & $\begin{array}{l}\text { Inhibited adipogenic and lipogenic gene } \\
\text { expression }\end{array}$ & [188] \\
\hline Sarconema filiforme & Carrageenan & In vivo & $\begin{array}{c}\text { Modulated gut microbiota } \\
\text { Reduced body weight and lipid } \\
\text { accumulation }\end{array}$ & [84] \\
\hline \multicolumn{5}{|c|}{ Green Seaweed (Chlorophyta) } \\
\hline Codium cylindricum & Siphonaxanthin & In vitro and in vivo & $\begin{array}{c}\text { Accumulated in stomach, small intestine, } \\
\text { liver, and adipose tissues } \\
\text { Modulated gut microbiota }\end{array}$ & [109] \\
\hline Codium fragile & Crude extract & In vivo & $\begin{array}{l}\text { Reduced body weight and accumulation } \\
\text { of cholesterol and glucose }\end{array}$ & [30] \\
\hline Codium cylindricum & Siphonaxanthin & In vitro and in vivo & $\begin{array}{l}\text { Reduced oxidative and somatic stress on } \\
\text { obese mice }\end{array}$ & [189] \\
\hline
\end{tabular}

The mechanism of obesity is shown in Figure 4e. Obesity upregulates proinflammatory cytokines such as tumor necrosis factor (TNF)- $\alpha$, interleukin (IL)-1 $\beta$, IL-6, and leptin; TNF$\alpha$ and IL- $1 \beta$ subsequently mediate the regulation of matrix metalloproteinases (MMPs) such as MMP-1, MMP-3, MMP-10, MMP-12, and MMP-1310-12 by stimulating the nuclear factorkappa B (NF- $\mathrm{kB}$ ) pathway. MMP levels are also influenced by mitogen-activated protein kinases (MAPKs), such as ERK1/2, c-Jun NH2-terminal kinase, and p38 subfamilies [190]. A high-fat diet increases the levels of gut inflammatory cytokines such as TNF- $\alpha$, IL- $1 \beta$, and IL-12, which are linked to weight gain, adiposity, and enhanced plasma insulin and glucose levels [191]. Obesity-related diseases such as metabolic syndrome may be reduced with an intervention that decreases gut and systemic inflammation [192]. Modulating the gut microbiota seems to be an option for reducing obesity [30]. Moreover, siphonaxanthin from Codium cylindricum showed anti-obesity activity since it accumulates in the stomach and small intestine, while its metabolites are absorbed and accumulated in the white adipose tissue (WAT) [109].

In addition, elevated $\mathrm{aP2}, \mathrm{ACC}$, and PPAR $\gamma$ gene expression levels cause excessive fat accumulation [181]. Sargassum miyabei and Saccorhiza polyschides exhibited anti-obesity effects by downregulating adipogenic and lipogenic gene expression, and intestinal and systemic glucose metabolism, thus inhibiting $\alpha$-amylase activity $[179,180]$. Furthermore, Plocamium telfairiae [188] and Gelidium amansii [187] also inhibited adipogenic and lipogenic gene expression in 3T3-L1 preadipocytes. In vivo, seaweed reduced body weight, triglyc- 
erides, total glucose, fatty liver, and white adipose tissue in the tested animals $[43,188]$. Frequently bioactive compounds that are found in seaweed for anti-obesity activity are fucosterol $[183,184]$ and phlototannin $[96,185]$. Previous studies have reported that siphonaxanthin, a carotenoid from Codium cylindricum, can restore antioxidative capacity and reduce somatic stress in obese mice [189].

\subsection{Cardiovascular Disease}

Seaweeds are increasingly in demand because they contain dietary fiber, peptides, and carotenoids that have the potential to prevent cardiovascular disease (CVD) [193]. Cardiovascular disease refers to a group of heart- and blood-vessel disorders, including coronary heart disease, cerebrovascular disease, peripheral artery disease, congenital heart disease, rheumatic heart disease, deep vein thrombosis, and pulmonary embolism [194]. The effects of seaweed-derived compounds on cardiovascular disease are shown in Table 6.

Table 6. The effects of seaweed-derived compounds on cardiovascular disease.

\begin{tabular}{|c|c|c|c|c|}
\hline Algal Source & $\begin{array}{l}\text { Compound of Interest } \\
\text { and Fraction }\end{array}$ & Study Type & Biological Effects & Ref. \\
\hline \multicolumn{5}{|c|}{ Brown Seaweed (Phaeophyceae) } \\
\hline Saccharina sculpera & Fucoidan & In vitro & $\begin{array}{l}\text { Inhibited cholesterol synthesis and } \\
\text { reverse transport } \\
\text { Modulated fatty acid synthesis } \\
\text { Accelerated mitochondrial } \beta \text {-oxidation }\end{array}$ & [195] \\
\hline Iyengaria stellata & Ethanol extract & In vivo & $\begin{array}{l}\text { Great inhibition of the lipid profile in } \\
\text { diet-induced hyperlipidemic rats }\end{array}$ & [196] \\
\hline Colpomenia sinuosa & Ethanol extract & In vivo & Reduced lipid profile & [196] \\
\hline Spatoglossum asperum & Ethanol extract & In vivo & $\begin{array}{l}\text { Combination with triton showed great } \\
\text { inhibition of the lipid profile in } \\
\text { triton-induced hyperlipidemic rats }\end{array}$ & [196] \\
\hline Ascophyllum nodosum & Fucoidan A2 & In vivo & $\begin{array}{l}\text { Reduced lipid profile, including plasma } \\
\text { total cholesterol, triglyceride, and fat pad } \\
\text { index }\end{array}$ & [29] \\
\hline Ascophyllum nodosum & Fucoidan A3 & In vivo & $\begin{array}{l}\text { Reduced lipid profile, including plasma } \\
\text { total cholesterol, triglyceride, and fat pad } \\
\text { index }\end{array}$ & [197] \\
\hline Cladosiphon okamuranus & Fucoidan & In vivo & Reduced lipid profile via reverse transport & [155] \\
\hline Ecklonia cava & Phlorotannin & In vivo & Reduced lipid profile via reverse transport & [198] \\
\hline Fucus spiralis & $\begin{array}{l}\text { Peptide and } \\
\text { phlorotannins }\end{array}$ & In vitro & Highly inhibited ACE-I yield & [199] \\
\hline Sargassum siliquastrum & Sargachromenol D & In vitro and in vivo & $\begin{array}{l}\text { Exerted antagonist of L-type } \mathrm{Ca}^{2+} \text { channel } \\
\text { and endothelin } \mathrm{A} / \mathrm{B} 2 \text { receptors }\end{array}$ & [200] \\
\hline Ecklonia cava & $\begin{array}{l}\text { Polyphenol extract and } \\
\text { dieckol }\end{array}$ & In vitro and in vivo & $\begin{array}{l}\text { Reduced lipid profile in the serum of } \\
\text { HFD-fed mice } \\
\text { Reduced lipid accumulation in 3T3-L1 } \\
\text { cells }\end{array}$ & [201] \\
\hline \multicolumn{5}{|c|}{ Red Seaweed (Rhodophyta) } \\
\hline Solieria robusta & Ethanol extract & In vivo & $\begin{array}{l}\text { Great inhibition of the lipid profile in } \\
\text { diet-induced hyperlipidemic rats }\end{array}$ & [196] \\
\hline \multicolumn{5}{|c|}{ Green Seaweed (Chlorophyta) } \\
\hline Caulerpa racemosa & Ethanol extract & In vivo & Reduced lipid profile & [196] \\
\hline
\end{tabular}

The mechanism of cardiovascular disease is shown in Figure 4f. The inhibition of angiotensin I-converting enzyme (ACE-I) is a well-established approach for the treatment of hypertension [194]. Paiva et al. [199] suggested that phenolic content and amino acid profiles, such as peptides and phlorotannins, possessed a higher inhibitory effect on ACEI yield [199]. Furthermore, Sargachromenol D from Sargassum siliquastrum could have 
antihypertensive activity, as it can function as an antagonist of the L-type $\mathrm{Ca}^{2+}$ channel and endothelin A/B2 receptors.

Dyslipidemia is a major risk factor for the development of atherosclerosis and related CVDs and is a major cause of death in many countries. Dyslipidemia is commonly characterized by elevated levels of total cholesterol (TC), triglyceride (TG), and low-density lipoprotein cholesterol (LDL-C), and decreased levels of high-density lipoprotein cholesterol (HDL-C) in the blood [202]. A previous study suggested that fucoidan of Saccharina sculpera may inhibit cholesterol synthesis and reverse transport by downregulating HMG-CoA-R; upregulating LCAT; modulating fatty acid synthesis by downregulating SREBP-1c; and accelerating mitochondrial $\beta$-oxidation by upregulation of PPAR $\alpha$, PPAR $\gamma$, and LPL [195]. Several seaweeds from the Karachi coast showed hypolipidemic effects by reducing the lipid profile. Solieria robusta was found to be the most effective in reducing the lipid profile in diet-induced hyperlipidemic rats among Iyengaria stellata, Colpomenia sinuosa, Spatoglossum asperum, and Caulerpa racemosa [196]. In addition, both fucoidan A2 and A3 from Ascophyllum nodosum reduced the lipid profile, including plasma total cholesterol, triglyceride, and fat pad index, by regulating reverse cholesterol transport (RCT) $[29,197]$. Cardioprotection was also shown in a study by Thomes et al., who found that Cladosiphon okamuranus fucoidan reduced the lipid profile-including total cholesterol, triglycerides, and low-density lipoprotein (LDL) - via reverse transport isoproterenol-induced myocardial infarction in rats [155], and phlorotannin from Ecklonia cava in a DOX-induced rat cardiotoxicity model [198]. Other studies have reported that polyphenol extract and dieckol Ecklonia cava may reduce lipid profiles in the serum of mice fed a high fat diet (HFD), and reduce lipid accumulation in 3T3-L1 cells [201].

\subsection{Arthritis}

Arthritis is the most common chronic inflammatory disease; it is characterized by structural and biochemical changes in major joint tissues, including cartilage matrix degradation and insufficient extracellular matrix synthesis (ECM), resulting in pain, stiffness, and joint failure $[203,204]$. Arthritis consists of several types, such as juvenile idiopathic arthritis (JIA) [205], psoriatic arthritis [206], gouty arthritis [207], rheumatoid arthritis (the most common form) [208], and osteoarthritis (OA) [209]. Previous studies on the potential of seaweed compounds for arthritis treatment are reported in Table 7.

Table 7. The effect of seaweed-derived compounds on arthritis.

\begin{tabular}{|c|c|c|c|c|}
\hline Algal Source & Constituents & Study Type & Biological Effects & Ref. \\
\hline \multicolumn{5}{|c|}{ Brown Seaweed (Phaeophyceae) } \\
\hline Ecklonia cava & Phlorotannins & In vitro & $\begin{array}{c}\text { Downregulated pro-inflammatory } \\
\text { cytokines }\end{array}$ & [13] \\
\hline Undaria pinnatifida & Fucoidan & In vitro and in vivo & $\begin{array}{c}\text { Downregulated pro-inflammatory } \\
\text { cytokines }\end{array}$ & [75] \\
\hline Lobophora variegata & Fucan & In vitro and in vivo & Reduced articular inflammation & [210] \\
\hline Sargassum wightii & Alginic acid & In vivo & $\begin{array}{c}\text { Downregulated pro-inflammatory } \\
\text { cytokines }\end{array}$ & [211] \\
\hline Sargassum wightii & Alginic acid & In vivo & $\begin{array}{c}\text { Downregulated pro-inflammatory } \\
\text { cytokines }\end{array}$ & [34] \\
\hline Fucus vesiculosis & Fucoidan & Clinical study & $\begin{array}{l}\text { Reduced the symptoms of osteoarthritis } \\
\text { in a dose-dependent manner }\end{array}$ & [12] \\
\hline Macrocystis pyrifera, & Fucoidan & Clinical study & $\begin{array}{l}\text { Reduced the symptoms of osteoarthritis } \\
\text { in a dose-dependent manner }\end{array}$ & [12] \\
\hline $\begin{array}{l}\text { Laminaria } \\
\text { japonica }\end{array}$ & Fucoidan & Clinical study & $\begin{array}{l}\text { Reduced the symptoms of osteoarthritis } \\
\text { in a dose-dependent manner }\end{array}$ & [12] \\
\hline
\end{tabular}


Table 7. Cont.

\begin{tabular}{|c|c|c|c|c|}
\hline Algal Source & Constituents & Study Type & Biological Effects & Ref. \\
\hline \multicolumn{5}{|c|}{ Red Seaweed (Rhodophyta) } \\
\hline Eucheuma cottonii & Polysaccharide-rich & In vitro & Attenuated cartilage degradation & [190] \\
\hline Laurencia glandulifera & Neorogioltriol & In vitro and in vivo & $\begin{array}{c}\text { Downregulated pro-inflammatory } \\
\text { cytokines }\end{array}$ & {$[212]$} \\
\hline \multicolumn{5}{|c|}{ Green Seaweed (Chlorophyta) } \\
\hline Codium fragile & Oleamide & In vitro and in vivo & $\begin{array}{c}\text { Downregulated pro-inflammatory } \\
\text { cytokines }\end{array}$ & [213] \\
\hline Caulerpa cupressoides & Lectin & In vivo & $\begin{array}{l}\text { Reduced temporomandibular joint } \\
\text { inflammation }\end{array}$ & [112] \\
\hline
\end{tabular}

Among several types of arthritis, seaweed bioactivity against $\mathrm{OA}$ is the most widely reported. OA is a common type of arthritis that primarily affects the knee [104]. A previous study suggested that $\mathrm{OA}$ joint degeneration results from a combination of mechanical stresses and biochemical factors, such as ROS and MMPs, which act as precursors to proinflammatory cytokines, including IL- $1 \alpha$, IL-1 $\beta$, and TNF- $\alpha$ [204,214]. As a result, cartilage degradation was attenuated in the model tested [190]. Previous studies have reported that phlorotannin-rich extracts isolated from Ecklonia cava reduce inflammation by downregulating pro-inflammatory cytokines [13]. Moreover, Lobophora variegate fucan reduced articular inflammation by downregulating paw edema and serum TNF- $\alpha$ [210]. Meanwhile, Laurencia glandulifera and Codium fragile exhibited anti-OA effects by inhibiting NF- $\mathrm{KB}$ activity and COX-2 expression in RAW264.7 cells in vitro, and reduced carrageenan-induced rat edema in vivo [212,213]. A study by Rivanor et al. [112] reported that Caulerpa cupressoides lectin may reduce leukocyte influx and the expression levels of pro-inflammatory cytokines, including IL- $1 \beta$ and TNF- $\alpha$, in the temporomandibular joint. The mechanism of OA is shown in Figure 4g.

Research on the benefits of seaweed for the treatment of OA was conducted in a clinical study by combining Phase I and II trials [12]. The formulation used contained Maritech ${ }^{\circledR}$ fucoidan-rich extracts of Fucus vesiculosis, Macrocystis pyrifera, and Laminaria japonica, with additional vitamin B6, zinc, and manganese taken daily. The study was conducted for 12 weeks in 11 participants, and for 10 weeks in one participant. A multilevel linear model revealed a decrease of $18 \%$ for the $100 \mathrm{mg}$ treatment and of $52 \%$ for the $1000 \mathrm{mg}$ dose in the average COAT score at the end of the study. This result suggests that treatment should be conducted for more than 12 weeks in a dose-dependent manner to reduce the symptoms of OA. A phase III randomized controlled trial (RCT) must be conducted to ensure its safety.

Rheumatoid arthritis is a chronic joint disorder affecting the cartilage and subchondral bone, affecting approximately $1 \%$ of the world's population. The fucoidan derivative of Undaria pinnatifida showed potential as a rheumatoid arthritis agent both in vitro and in vivo by downregulating pro-inflammatory cytokines such as COX-2 expression [75]. Other studies have reported that alginic acid from Sargassum wightii may downregulate proinflammatory cytokines such as cycloxygenase-2 (COX-2), lipoxygenase (5-LOX), xanthine oxidase (XO), and myeloperoxidase (MPO) in adjuvant-induced arthritis [211] and type II collagen-induced arthritis rat models [34].

\subsection{Osteoporosis}

Osteoporosis is a major public health issue affecting the aging population, characterized by low bone mass. Osteoporosis is linked to decreased bone formation by osteoblasts and increased bone resorption by osteoclasts; these lead to microarchitectural deterioration of bone tissue, excessive bone fragility, and increased bone fracture risk $[11,215,216]$. In recent years, natural products from seaweed have been explored and investigated more specifically as sources for osteoporosis treatment. Studies on the osteoprotective activity of seaweeds are summarized in Table 8 . 
Table 8. The effect of seaweed-derived compounds on osteoporosis.

\begin{tabular}{|c|c|c|c|c|}
\hline Algal Source & Constituents & Study Type & Biological Effects & Ref. \\
\hline \multicolumn{5}{|c|}{ Brown Seaweed (Phaeophyceae) } \\
\hline Dictyota mertensii & Fucoidan & In vitro & $\begin{array}{c}\text { Protected bone tissue against oxidative } \\
\text { stress }\end{array}$ & [217] \\
\hline Laminaria digitata & Fucoxanthin & In vitro & Low pro-osteogenic effects & [11] \\
\hline Ascophyllum nodosum & Fucoxanthin & In vitro & Low pro-osteogenic effects & {$[11]$} \\
\hline Padina pavonica & Acetonic extract & In vitro & $\begin{array}{l}\text { Promoted osteoblast differentiation } \\
\text { Regulated osteoblast-specific markers }\end{array}$ & [218] \\
\hline Sargassum hemiphyllum & Fucoidan & In vitro & $\begin{array}{l}\text { Protected osteoclast differentiation and } \\
\text { inflammatory bone loss }\end{array}$ & [219] \\
\hline Ishige okamurae & $\begin{array}{l}\text { Diphloretho- } \\
\text { hydroxycarmalol }\end{array}$ & In vitro & $\begin{array}{c}\text { Promoted osteoblastic differentiation from } \\
\text { oxidative stress }\end{array}$ & [220] \\
\hline \multicolumn{5}{|c|}{ Red Seaweed (Rhodophyta) } \\
\hline Plocamium lyngbyanum & Methanolic extract & In vitro and in vivo & $\begin{array}{l}\text { Promoted osteogenic differentiation and } \\
\text { mineralization } \\
\text { Increased opercular bone area }\end{array}$ & [221] \\
\hline Ceramium secundatum & Methanolic extract & In vitro and in vivo & $\begin{array}{l}\text { Promoted osteogenic differentiation and } \\
\text { mineralization } \\
\text { Increased opercular bone area }\end{array}$ & [221] \\
\hline Dichotomaria obtusata & Methanolic extract & In vitro & Upregulated osteogenic activity & [215] \\
\hline Gracilaria verrucosa & Crude extract & In vitro and in vivo & $\begin{array}{c}\text { Downregulated RANKL-induced } \\
\text { osteoclast differentiation } \\
\text { Inhibited bone loss }\end{array}$ & [33] \\
\hline Ceramium pallidum & $\begin{array}{l}\text { Dichloromethane and } \\
\text { methanol extract }\end{array}$ & In vitro and in vivo & $\begin{array}{c}\text { Promoted osteogenic differentiation and } \\
\text { mineralization } \\
\text { Increased opercular bone area }\end{array}$ & [216] \\
\hline \multicolumn{5}{|c|}{ Green Seaweed (Chlorophyta) } \\
\hline Cladophora rupestris & Phenolic extract & In vitro and in vivo & $\begin{array}{l}\text { Promoted osteoblast-like cell } \\
\text { mineralization } \\
\text { Increased opercular bone area }\end{array}$ & [222] \\
\hline Codium fragile & Phenolic extract & In vitro and in vivo & $\begin{array}{l}\text { Promoted osteoblast-like cell } \\
\text { mineralization } \\
\text { Increased opercular bone area }\end{array}$ & [222] \\
\hline
\end{tabular}

Some marine algae have been investigated for their beneficial effects as osteogenic agents because of their important minerals, such as manganese, zinc, calcium, and amino acids, which can promote bone metabolism [223]. Bone-forming cells include osteoblasts, osteocytes, and bone-lining cells, whereas osteoclasts participate in bone resorption [218]. Red seaweeds have been reported to have osteoprotective effects on osteogenic differentiation. Dichotomaria obtusata [215], Ceramium secundatum, and Plocamium lyngbyanum [221] methanolic extracts significantly upregulated osteogenic activity and increased mineralization of bone cells tested in vitro. Furthermore, Ceramium secundatum and Plocamium lyngbyanum increased the opercular bone area of zebrafish larvae in vivo [221]. Moreover, two powder-residue-derived extracts of Ceramium pallidum caused significant osteogenic differentiation and produced mineralogenic effects in vitro, and increased opercular bone and bone density in zebrafish larvae in vivo [216].

Antioxidant fucoidans from Dictyota mertensii protect pro-osteoblastic cells under oxidative stress by deregulating osteoblast activity [217]. Furthermore, Padina pavonica promotes pro-osteogenic effects by enhancing osteoblast differentiation and subsequent mineralization, as well as by regulating the expression of earlier osteoblast-specific markers [218]. In contrast, fucoxanthin from Laminaria digitata and Ascophyllum nodosum extract showed low pro-osteogenic activity in the two cell types tested [11]. Phenolic compounds from Cladophora rupestris and Codium fragile promoted osteoblast-like cells in vitro and the mineralized area in zebrafish larvae in vivo [7]. Diphlorethohydroxycamalol-derived 
phlorotannin isolated from Ishige okamurae showed anti-osteoporosis effects by upregulating osteoblast differentiation against $\mathrm{H}_{2} \mathrm{O}_{2}$-induced oxidative damage and promoting bone resorption, by decreasing the expression level of the receptor activator of NF- $\mathrm{kB}$ ligand [220].

The mechanism of osteoporosis is shown in Figure 4h. Osteoclasts are large multinucleated myeloid cells that can break down the bone matrix by proteolytic degradation and decalcification [224]. The receptor activator of nuclear factor- $\mathrm{kB}$ (RANKL) has been identified as an important transcription factor for osteoclast differentiation from the monocyte/macrophage lineage. Gracilaria verrucose downregulated RANKL-induced osteoclast differentiation by inhibiting the c-Fos-NFATc1 signaling pathway in vitro, and inhibited bone loss in an OVX mouse model when tested in vivo [33]. Meanwhile, fucoidan extract from Sargassum hemiphyllum prevents the differentiation of osteoclasts and inflammatory bone loss by regulating the Akt/GSK3 $\beta /$ PTEN/NFATc1 signaling pathway and calcineurin activity [219].

\section{Conclusions}

The use of seaweeds as food and medicine has a long history, and the benefit of seaweeds for health have been revealed. Many published studies have demonstrated that extracts from seaweeds can contribute to the reduction and modulation of several chronic diseases. However, most of the studies have been conducted in vitro and in vivo, and only three seaweed studies have been conducted at the clinical stage. Hence, further clinical studies involving human subjects are required to confirm these therapeutic effects. Results from clinical studies will provide useful information for understanding the mechanisms underlying the effects of seaweed in modulating chronic diseases. Furthermore, the bioactive compounds in seaweed need to be purified and identified to better understand the mechanisms and pathways that they affect and, therefore, to develop them as functional food and nutraceutical products. Future research on the identification, isolation, and purification of seaweed's bioactive compounds and its mechanism to treat chronic diseases might provide a significant contribution to overcoming increasing chronic disease in the world.

Author Contributions: Conceptualization, M.D.N.M. and J.-S.C.; methodology, M.D.N.M.; software, D.H.; validation M.D.N.M., D.H. and J.-S.C.; formal analysis, M.D.N.M.; investigation, M.D.N.M.; resources, D.H.; data curation, D.H.; writing—original draft preparation, M.D.N.M. and J.-S.C.; writing-review and editing, M.D.N.M., D.H. and J.-S.C.; visualization, M.D.N.M. and D.H.; supervision, J.-S.C. All authors have read and agreed to the published version of the manuscript.

Funding: This research was supported by the Ministry of Oceans and Fisheries and Busan Metropoli tan City through the Capacity Building Project for the Development of the Busan Seafood IndustryBased Complex.

Data Availability Statement: Data supporting reported results are available upon request.

Acknowledgments: We thank to Silla University, Jenderal Soedirman University and Diponegoro University for the reseach collaboration.

Conflicts of Interest: The authors declare that they have no conflicts of interest to declare.

\section{References}

1. Holdt, S.L.; Kraan, S. Bioactive compounds in seaweed: Functional food applications and legislation. J. Appl. Phycol. 2011, 23, 543-597. [CrossRef]

2. Plasek, B.; Lakner, Z.; Kasza, G.; Temesi, Á. Consumer evaluation of the role of functional food products in disease prevention and the characteristics of target groups. Nutrients 2020, 12, 69. [CrossRef]

3. Mendis, E.; Kim, S.K. Present and future prospects of seaweeds in developing functional foods. Adv. Food Nutr. Res. 2011, 64, 1-15. [CrossRef]

4. Neto, R.T.; Marçal, C.; Queirós, A.S.; Abreu, H.; Silva, A.M.S.; Cardoso, S.M. Screening of Ulva rigida, Gracilaria sp., Fucus vesiculosus and Saccharina latissima as functional ingredients. Int. J. Mol. Sci. 2018, 19, 2987. [CrossRef]

5. Pandey, A.; Chauhan, O.; Semwal, A. Pandey 2020. Seaweeds-A Potential Source for Functional Foods.pdf. Def. Life Sci. J. 2020, 5, 315-322. [CrossRef] 
6. Brown, E.M.; Allsopp, P.J.; Magee, P.J.; Gill, C.I.R.; Nitecki, S.; Strain, C.R. Seaweed and human health. Nutr. Rev. 2014, 72, 205-216. [CrossRef]

7. Leandro, A.; Pacheco, D.; Cotas, J.; Marques, J.C.; Pereira, L.; Gonçalves, A.M.M. Seaweed's Bioactive Candidate Compounds to Food Industry and Global Food Security. Life 2020, 10, 140. [CrossRef]

8. Sathivel, A.; Balavinayagamani; Rao, B.R.H.; Devaki, T. Sulfated polysaccharide isolated from Ulva lactuca attenuates Dgalactosamine induced DNA fragmentation and necrosis during liver damage in rats. Pharm. Biol. 2014, 52, 498-505. [CrossRef]

9. Lin, G.; Liu, X.; Yan, X.; Liu, D.; Yang, C.; Liu, B.; Huang, Y.; Zhao, C. Role of green macroalgae Enteromorpha prolifera polyphenols in the modulation of gene expression and intestinal microflora profiles in type 2 diabetic mice. Int. J. Mol. Sci. 2019, 20, 25. [CrossRef]

10. Jung, H.A.; Islam, M.N.; Lee, C.M.; Oh, S.H.; Lee, S.; Jung, J.H.; Choi, J.S. Kinetics and molecular docking studies of an antidiabetic complication inhibitor fucosterol from edible brown algae Eisenia bicyclis and Ecklonia stolonifera. Chem. Biol. Interact. 2013, 206, 55-62. [CrossRef]

11. Walsh, P.J.; McGrath, S.; McKelvey, S.; Ford, L.; Sheldrake, G.; Clarke, S.A. The osteogenic potential of brown seaweed extracts. Mar. Drugs 2019, 17, 141. [CrossRef] [PubMed]

12. Myers, S.P.; O'Connor, J.; Fitton, J.H.; Brooks, L.; Rolfe, M.; Connellan, P.; Wohlmuth, H.; Cheras, P.A.; Morris, C. A combined Phase I and II open-label study on the Immunomodulatory effects of seaweed extract nutrient complex. Biol. Targets Ther. 2011, 5, 45-60. [CrossRef] [PubMed]

13. Shin, H.; Hwang, H.J.; Kang, K.J.; Lee, B.H. An Antioxidative and Antiinflammatory Agent for Potential Treatment of Osteoarthritis from Ecklonia cava. Arch. Pharm. Res. 2006, 29, 165-171. [CrossRef] [PubMed]

14. Yan, X.; Yang, C.; Lin, G.; Chen, Y.; Miao, S.; Liu, B.; Zhao, C. Antidiabetic Potential of Green Seaweed Enteromorpha prolifera Flavonoids Regulating Insulin Signaling Pathway and Gut Microbiota in Type 2 Diabetic Mice. J. Food Sci. 2019, 84, 165-173. [CrossRef]

15. Paiva, L.; Lima, E.; Neto, A.I.; Marcone, M.; Baptista, J. Nutritional and Functional Bioactivity Value of Selected Azorean Macroalgae: Ulva compressa, Ulva rigida, Gelidium microdon, and Pterocladiella capillacea. J. Food Sci. 2017, 82, 1757-1764. [CrossRef]

16. Gray, J.; Armstrong, G.; Farley, H. Opportunities and constraints in the functional food market. Nutr. Food Sci. 2003, 33, 213-218. [CrossRef]

17. Plaza, M.; Santoyo, S.; Jaime, L.; Reina, G.G.-B.; Herrero, M.; Señoráns, F.J.; Ibáñez, E. Screening for bioactive compounds from algae. J. Pharm. Biomed. Anal. 2010, 51, 450-455. [CrossRef]

18. Pereira, L. A Review of The Nutrient Composition of Selected Edible Seaweed. In Seaweed: Ecology, Nutrient Composition and Medicinal Uses; Pomin, V.H., Ed.; Nova Science Publishers, Inc.: Coimbra, Portugal, 2011; ISBN 9781614708780.

19. McHugh, D.J. A Guide to the Seaweed Industry; Food and Agriculture Organization: Rome, Italy, 2003; ISBN 92-5-104958-0.

20. Kolanjinathan, K.; Ganesh, P.; Saranraj, P. Pharmacological Importance of Seaweeds: A Review. World J. Fish Mar. Sci. 2014, 6, 1-15. [CrossRef]

21. Bocanegra, A.; Bastida, S.; Benedí, J.; Ródenas, S.; Sánchez-muniz, F.J. Characteristics and Nutritional and Cardiovascular-Health Properties of Seaweeds. J. Med. Food 2009, 12, 236-258. [CrossRef]

22. Faggio, C.; Pagano, M.; Dottore, A.; Genovese, G.; Morabito, M. Evaluation of anticoagulant activity of two algal polysaccharides. Nat. Prod. Res. 2016, 30, 1934-1937. [CrossRef]

23. Iso, H.; Kubota, Y. Nutrition and Disease in the Japan Collaborative Cohort Study for Evaluation of Cancer (JACC). Asian Pac. J. Cancer Prev. 2007, 8, 35-80. [PubMed]

24. Kim, J.; Shin, A.; Lee, J.-S.; Youn, S.; Yoo, K.-Y. Dietary Factors and Breast Cancer in Korea: An Ecological Study. Breast J. 2020, 15, 683-686. [CrossRef] [PubMed]

25. Park, J.-K.; Woo, H.W.; Kim, M.K.; Shin, J.; Lee, Y.-H.; Shin, D.H.; Shin, M.-H.; Choi, B.Y. Dietary iodine, seaweed consumption, and incidence risk of metabolic syndrome among postmenopausal women: A prospective analysis of the Korean Multi-Rural Communities Cohort Study (MRCohort). Eur. J. Nutr. 2020, 60, 135-146. [CrossRef] [PubMed]

26. Iso, H. Lifestyle and Cardiovascular Disease in Japan. J. Atheroscler. Thromb. 2010, 18, 83-88. [CrossRef] [PubMed]

27. Michikawa, T.; Inoue, M.; Shimazu, T.; Sawada, N. Seaweed consumption and the risk of thyroid cancer in women: The Japan Public Health Center-based Prospective Study and for the Japan Public Health Center-based Prospective Study Group. Eur. J. Cancer Prev. 2008, 21, 254-260. [CrossRef]

28. Hu, P.; Li, Z.; Chen, M.; Sun, Z.; Ling, Y.; Jiang, J.; Huang, C. Structural elucidation and protective role of a polysaccharide from Sargassum fusiforme on ameliorating learning and memory deficiencies in mice. Carbohydr. Polym. 2016, 139, 150-158. [CrossRef]

29. Yang, Z.; Liu, G.; Wang, Y.; Yin, J.; Wang, J.; Xia, B.; Li, T.; Yang, X.; Hou, P.; Hu, S.; et al. Fucoidan A2 from the Brown Seaweed Ascophyllum nodosum Lowers Lipid by Improving Reverse Cholesterol Transport in C57BL/6J Mice Fed a High-Fat Diet. J. Agric. Food Chem. 2019, 67, 5782-5791. [CrossRef]

30. Kim, J.; Choi, J.H.; Oh, T.; Ahn, B.; Unno, T. Codium fragile Ameliorates High-Fat Diet-Induced Metabolism by Modulating the Gut Microbiota in Mice. Nutrients 2020, 12, 1848. [CrossRef]

31. Mary, J.S.; Vinotha, P.; Pradeep, A.M. Screening for in vitro cytotoxic activity of seaweed, Sargassum sp. against hep-2 and MCF-7 cancer cell lines. Asian Pac. J. Cancer Prev. 2012, 13, 6073-6076. [CrossRef] 
32. Quintal-novelo, C.; Rangel-méndez, J.; Ortiz-tello, Á.; Graniel-sabido, M.; De Vaca, R.P.; Moo-puc, R. A Sargassum fluitans Borgesen Ethanol Extract Exhibits a Hepatoprotective Effect In Vivo in Acute and Chronic Liver Damage Models. BioMed Res. Int. 2018, 2018, 6921845. [CrossRef]

33. Kim, K.J.; Lee, Y.J.; Hwang, Y.H.; Kang, K.Y.; Yee, S.T.; Son, Y.J. In vitro and in vivo effects of Gracilaria verrucosa extracts on osteoclast differentiation. J. Clin. Med. 2017, 6, 32. [CrossRef] [PubMed]

34. Sarithakumari, C.H.; Kurup, G.M. International Immunopharmacology Alginic acid isolated from Sargassum wightii exhibits antiinflammatory potential on type II collagen induced arthritis in experimental animals. Int. Immunopharmacol. 2013, 17, 1108-1115. [CrossRef] [PubMed]

35. Moher, D.; Liberati, A.; Tetzlaff, J.; Altman, D.G.; Altman, D.; Antes, G.; Atkins, D.; Barbour, V.; Barrowman, N.; Berlin, J.A.; et al. Preferred reporting items for systematic reviews and meta-analyses: The PRISMA statement. PLoS Med. 2009, 6, e1000097. [CrossRef] [PubMed]

36. Myers, S.P.; Connor, J.O.; Fitton, J.H.; Brooks, L.; Rolfe, M.; Connellan, P.; Wohlmuth, H.; Cheras, P.A.; Morris, C. A combined phase I and II open label study on the effects of a seaweed extract nutrient complex on osteoarthritis. Biologics 2010, 4, 33-44. [CrossRef]

37. Garcia-Vaquero, M.; Rajauria, G.; Miranda, M.; Sweeney, T.; Lopez-Alonso, M.; O'Doherty, J. Seasonal Variation of the Proximate Composition, Mineral Content, Fatty Acid Profiles and Other Phytochemical Constituents of Selected Brown Macroalgae. Mar. Drugs 2021, 19, 204. [CrossRef]

38. Rajauria, G. Optimization and validation of reverse phase HPLC method for qualitative and quantitative assessment of polyphenols in seaweed. J. Pharm. Biomed. Anal. 2018, 148, 230-237. [CrossRef]

39. Khairy, H.M.; El-Shafay, S.M. Seasonal variations in the biochemical composition of some common seaweed species from the coast of Abu Qir Bay, Alexandria, Egypt. Oceanologia 2013, 55, 435-452. [CrossRef]

40. Banerjee, K.; Ghosh, R.; Homechaudhuri, S.; Mitra, A. Seasonal variation in the biochemical composition of red seaweed (Catenella repens) from Gangetic delta, northeast coast of India. J. Earth Syst. Sci. 2009, 118, 497-505. [CrossRef]

41. Rioux, L.E.; Turgeon, S.L. Seaweed Carbohydrates; Elsevier Inc.: Amsterdam, The Netherlands, 2015; ISBN 9780124199583.

42. Stiger-Pouvreau, V.; Bourgougnon, N.; Deslandes, E. Carbohydrates from Seaweeds; Elsevier Inc.: Amsterdam, The Netherlands, 2016; ISBN 9780128027936.

43. Yang, T.H.; Chiu, C.Y.; Lu, T.J.; Liu, S.H.; Chiang, M.T. The Anti-Obesity Effect of Polysaccharide-Rich Red Algae (Gelidium amansii) Hot-Water Extracts in High-Fat Diet-Induced Obese Hamsters. Mar. Drugs 2019, 17, 532. [CrossRef]

44. Bauer, S.; Jin, W.; Zhang, F.; Linhardt, R.J. The Application of Seaweed Polysaccharides and Their Derived Products with Potential for the Treatment of Alzheimer's Disease. Mar. Drugs 2021, 19, 89. [CrossRef]

45. Usman, A.; Khalid, S.; Usman, A.; Hussain, Z.; Wang, Y. Algal Polysaccharides, Novel Application, and Outlook. In Algae Based Polymers, Blends, and Composites: Chemistry, Biotechnology and Materials Science; Elsevier: Amsterdam, The Netherlands, 2017; pp. 115-153. [CrossRef]

46. Lee, S.Y.; Chang, J.H.; Lee, S.B. Chemical composition, saccharification yield, and the potential of the green seaweed Ulva pertusa. Biotechnol. Bioprocess Eng. 2014, 19, 1022-1033. [CrossRef]

47. Nunraksa, N.; Rattanasansri, S.; Praiboon, J.; Chirapart, A. Proximate composition and the production of fermentable sugars, levulinic acid, and HMF from Gracilaria fisheri and Gracilaria tenuistipitata cultivated in earthen ponds. J. Appl. Phycol. 2019, 31, 683-690. [CrossRef]

48. Wang, L.; Jayawardena, T.U.; Yang, H.W.; Lee, H.G.; Kang, M.C.; Sanjeewa, K.K.A.; Oh, J.Y.; Jeon, Y.J. Isolation, characterization, and antioxidant activity evaluation of a fucoidan from an enzymatic digest of the edible seaweed, Hizikia fusiforme. Antioxidants 2020, 9, 363. [CrossRef] [PubMed]

49. Cherry, P.; O’hara, C.; Magee, P.J.; Mcsorley, E.M.; Allsopp, P.J. Risks and benefits of consuming edible seaweeds. Nutr. Rev. 2019, 77, 307-329. [CrossRef]

50. Kawaroe, M.; Sari, D.W.; Hwangbo, J.; Santoso, J. Optimum fermentation process for red macroalgae Gelidium latifolium and Gracillaria verrucosa. J. Eng. Technol. Sci. 2015, 47, 674-687. [CrossRef]

51. Lu, Y.A.; Lee, H.G.; Li, X.; Hyun, J.M.; Kim, H.S.; Kim, T.H.; Kim, H.M.; Lee, J.J.; Kang, M.C.; Jeon, Y.J. Anti-obesity effects of red seaweed, Plocamium telfairiae, in C57BL/ 6 mice fed a high-fat diet. Food Funct. 2020, 11, 2299-2308. [CrossRef]

52. Zheng, T.; Liu, C.; Yang, J.; Liu, Q.; Li, J. Hijiki seaweed (Hizikia fusiformis): Nutritional value, safety concern and arsenic removal method. Adv. Mater. Res. 2013, 634-638, 1247-1252. [CrossRef]

53. Galland-Irmouli, A.V.; Fleurence, J.; Lamghari, R.; Luçon, M.; Rouxel, C.; Barbaroux, O.; Bronowicki, J.P.; Villaume, C.; Guéant, J.L. Nutritional value of proteins from edible seaweed Palmaria palmata (Dulse). J. Nutr. Biochem. 1999, 10, 353-359. [CrossRef]

54. Fleurence, J. Seaweed Proteins; Woodhead Publishing Limited: Sawston, UK, 2004; ISBN 9781855737235.

55. Lafarga, T.; Acién-fernández, F.G.; Garcia-vaquero, M. Bioactive peptides and carbohydrates from seaweed for food applications: Natural occurrence, isolation, purification, and identification. Algal Res. 2020, 48, 101909. [CrossRef]

56. Prabhasankar, P.; Ganesan, P.; Bhaskar, N.; Hirose, A.; Stephen, N.; Gowda, L.R.; Hosokawa, M.; Miyashita, K. Edible Japanese seaweed, wakame (Undaria pinnatifida) as an ingredient in pasta: Chemical, functional and structural evaluation. Food Chem. 2009, 115, 501-508. [CrossRef]

57. Rajapakse, N.; Kim, S.K. Nutritional and Digestive Health Benefits of Seaweed. Adv. Food Nutr. Res. 2011, 64, 17-28. 
58. Meinita, M.D.N.; Harwanto, D.; Sohn, J.-H.; Kim, J.-S.; Choi, J.-S. Hizikia fusiformis: Pharmacological and Nutritional Properties. Foods 2021, 10, 1660. [CrossRef] [PubMed]

59. Meinita, M.D.N.; Harwanto, D.; Tirtawijaya, G.; Negara, B.F.S.P.; Sohn, J.H.; Kim, J.S.; Choi, J.S. Fucosterol of marine macroalgae: Bioactivity, safety and toxicity on organism. Mar. Drugs 2021, 19, 545. [CrossRef] [PubMed]

60. Peñalver, R.; Lorenzo, J.M.; Ros, G.; Amarowicz, R.; Pateiro, M.; Nieto, G. Seaweeds as a functional ingredient for a healthy diet. Mar. Drugs 2020, 18, 301. [CrossRef]

61. Gamero-Vega, G.; Palacios-Palacios, M.; Quitral, V. Nutritional Composition and Bioactive Compounds of Red Seaweed: A Mini-Review. J. Food Nutr. Res. 2020, 8, 431-440. [CrossRef]

62. Choi, J.; Kim, K.J.; Koh, E.J.; Lee, B.Y. Gelidium elegans extract ameliorates type 2 diabetes via regulation of MAPK and PI3K/Akt signaling. Nutrients 2018, 10, 51. [CrossRef]

63. Nisizawa, K.; Noda, H.; Kikuchi, R.; Watanabe, T. The main seaweed foods in Japan. Hydrobiologia 1987, 151-152, 5-29. [CrossRef]

64. European Food Safety Authority. Scientific Opinion on Dietary Reference Values for carbohydrates and dietary fibre. EFSA J. 2010, 8, 1462. [CrossRef]

65. Xu, S.Y.; Huang, X.; Cheong, K.L. Recent advances in marine algae polysaccharides: Isolation, structure, and activities. Mar. Drugs 2017, 15, 388. [CrossRef]

66. MacArtain, P.; Gill, C.I.R.; Brooks, M.; Campbell, R.; Rowland, I.R. Nutritional value of edible seaweeds. Nutr. Rev. 2007, 65, 535-543. [CrossRef]

67. Muraguri, E.N.; Wakibia, J.G.; Kinyuru, J.N. Chemical Composition and Functional Properties of Selected Seaweeds from the Kenya Coast. J. Food Res. 2016, 5, 114. [CrossRef]

68. Ale, M.T.; Meyer, A.S. Fucoidans from brown seaweeds: An update on structures, extraction techniques and use of enzymes as tools for structural elucidation. RSC Adv. 2013, 3, 8131-8141. [CrossRef]

69. Wang, Y.; Xing, M.; Cao, Q.; Ji, A.; Liang, H.; Song, S. Biological activities of fucoidan and the factors mediating its therapeutic effects: A review of recent studies. Mar. Drugs 2019, 17, 183. [CrossRef] [PubMed]

70. Salehi, B.; Sharifi-rad, J.; Seca, A.M.L.; Pinto, D.C.G.A. Current Trends on Seaweeds: Looking at Chemical. Molecules 2019, $24,4182$. [CrossRef]

71. Yin, J.; Wang, J.; Li, F.; Yang, Z.; Yang, X.; Sun, W.; Xia, B.; Li, T.; Song, W.; Guo, S. The fucoidan from the brown seaweed: Ascophyllum nodosum ameliorates atherosclerosis in apolipoprotein E-deficient mice. Food Funct. 2019, 10, 5124-5139. [CrossRef]

72. Wu, S.Y.; Yan, M.D.; Wu, A.T.H.; Yuan, K.S.P.; Liu, S.H. Brown Seaweed Fucoidan Inhibits Cancer Progression by Dual Regulation of mir-29c/ADAM12 and miR-17-5p/PTEN Axes in Human Breast Cancer Cells. J. Cancer 2016, 7, 2408-2419. [CrossRef]

73. Meenakshi, S.; Umayaparvathi, S.; Saravanan, R.; Manivasagam, T.; Balasubramanian, T. International Journal of Biological Macromolecules Hepatoprotective effect of fucoidan isolated from the seaweed Turbinaria decurrens in ethanol intoxicated rats. Int. J. Biol. Macromol. 2014, 67, 367-372. [CrossRef]

74. Rupérez, P.; Ahrazem, O.; Leal, J.A. Potential antioxidant capacity of sulfated polysaccharides from the edible marine brown seaweed Fucus vesiculosus. J. Agric. Food Chem. 2002, 50, 840-845. [CrossRef]

75. Phull, A.R.; Majid, M.; Haq, I.U.; Khan, M.R.; Kim, S.J. In vitro and in vivo evaluation of anti-arthritic, antioxidant efficacy of fucoidan from Undaria pinnatifida (Harvey) Suringar. Int. J. Biol. Macromol. 2017, 97, 468-480. [CrossRef]

76. Patel, S. Therapeutic importance of sulfated polysaccharides from seaweeds: Updating the recent findings. 3 Biotech 2012, 2, 171-185. [CrossRef]

77. Okolie, C.L.; Subin, S.R.; Udenigwe, C.C.; Aryee, A.N.A.; Mason, B. Prospects of brown seaweed polysaccharides (BSP) as prebiotics and potential immunomodulators. J. Food Biochem. 2017, 41, e12392. [CrossRef]

78. Cotas, J.; Leandro, A.; Pacheco, D.; Gonçalves, A.M.M.; Pereira, L. A comprehensive review of the nutraceutical and therapeutic applications of red seaweeds (Rhodophyta). Life 2020, 10, 19. [CrossRef] [PubMed]

79. Hemmingson, J.A.; Furneaux, R.H.; Murray-Brown, V.H. Biosynthesis of agar polysaccharides in Gracilaria chilensis bird, McLachlan et Oliveira. Carbohydr. Res. 1996, 287, 101-115. [CrossRef]

80. Patil, N.P.; Le, V.; Sligar, A.D.; Mei, L.; Chavarria, D.; Yang, E.Y.; Baker, A.B. Algal Polysaccharides as Therapeutic Agents for Atherosclerosis. Front. Cardiovasc. Med. 2018, 5, 153. [CrossRef]

81. Torres, M.D.; Flórez-Fernández, N.; Domínguez, H. Integral utilization of red seaweed for bioactive production. Mar. Drugs 2019, 17, 314. [CrossRef]

82. Jol, C.N.; Neiss, T.G.; Penninkhof, B.; Rudolph, B.; De Ruiter, G.A. A novel high-performance anion-exchange chromatographic method for the analysis of carrageenans and agars containing 3,6-anhydrogalactose. Anal. Biochem. 1999, 268, 213-222. [CrossRef]

83. Necas, J.; Bartosikova, L. Carrageenan: A review. Vet. Med. (Praha) 2013, 58, 187-205. [CrossRef]

84. Preez, R.; Paul, N.; Mouatt, P.; Majzoub, M.E.; Thomas, T.; Panchal, S.K.; Brown, L. Carrageenans from the Red Seaweed Sarconema filiforme Attenuate Symptoms of Diet-Induced Metabolic Syndrome in Rats. Mar. Drugs 2020, 18, 97. [CrossRef]

85. Meinita, M.D.N.; Marhaeni, B.; Jeong, G.T.; Hong, Y.K. Sequential acid and enzymatic hydrolysis of carrageenan solid waste for bioethanol production: A biorefinery approach. J. Appl. Phycol. 2019, 31, 2507-2515. [CrossRef]

86. Van De Velde, F.; Lourenço, N.D.; Pinheiro, H.M.; Bakker, M. Carrageenan: A Food-Grade and Biocompatible Support for Immobilisation Techniques. Adv. Synth. Catal. 2002, 344, 815-835. [CrossRef]

87. Kidgell, J.T.; Magnusson, M.; de Nys, R.; Glasson, C.R.K. Ulvan: A systematic review of extraction, composition and function. Algal Res. 2019, 39, 101422. [CrossRef] 
88. Lahaye, M. NMR spectroscopic characterisation of oligosaccharides from two Ulva rigida ulvan samples (Ulvales, Chlorophyta) degraded by a lyase. Carbohydr. Res. 1998, 314, 1-12. [CrossRef]

89. Bixler, H.J.; Porse, H. A decade of change in the seaweed hydrocolloids industry. J. Appl. Phycol. 2011, 23, 321-335. [CrossRef]

90. Patterson, G.W. The distribution of sterols in algae. Lipids 1971, 6, 120-127. [CrossRef]

91. Bogie, J.; Hoeks, C.; Schepers, M.; Tiane, A.; Cuypers, A.; Leijten, F.; Chintapakorn, Y.; Suttiyut, T.; Pornpakakul, S.; Struik, D.; et al. Dietary Sargassum fusiforme improves memory and reduces amyloid plaque load in an Alzheimer's disease mouse model. Sci. Rep. 2019, 9, 4908. [CrossRef]

92. Hannan, M.A.; Sohag, A.A.M.; Dash, R.; Haque, M.N.; Mohibbullah, M.; Oktaviani, D.F.; Hossain, M.T.; Choi, H.J.; Moon, I.S. Phytosterols of marine algae: Insights into the potential health benefits and molecular pharmacology. Phytomedicine 2020, 69, 153201. [CrossRef] [PubMed]

93. Fernandes, P.; Cabral, J.M.S. Phytosterols: Applications and recovery methods. Bioresour. Technol. 2007, 98, 2335-2350. [CrossRef]

94. Gupta, S.; Abu-ghannam, N. Bioactive potential and possible health effects of edible brown seaweeds. Trends Food Sci. Technol. 2011, 22, 315-326. [CrossRef]

95. Xiao, X.H.; Yuan, Z.Q.; Li, G.K. Preparation of phytosterols and phytol from edible marine algae by microwave-assisted extraction and high-speed counter-current chromatography. Sep. Purif. Technol. 2013, 104, 284-289. [CrossRef]

96. Kwon, T.H.; Wu, Y.X.; Kim, J.S.; Woo, J.H.; Park, K.T.; Kwon, O.J.; Seo, H.J.; Kim, T.; Park, N.H. 6,6'-Bieckol inhibits adipocyte differentiation through downregulation of adipogenesis and lipogenesis in 3T3-L1 cells. J. Sci. Food Agric. 2015, 95, $1830-1837$. [CrossRef]

97. Jung, H.A.; Roy, A.; Jung, J.H.; Choi, J.S. Evaluation of the inhibitory effects of eckol and dieckol isolated from edible brown alga Eisenia bicyclis on human monoamine oxidases A and B. Arch. Pharm. Res. 2017, 40, 480-491. [CrossRef]

98. Myung, C.; Shin, H.; Bao, H.Y.; Yeo, S.J.; Lee, B.H.; Kang, J.S. Improvement of Memory by Dieckol and Phlorofucofuroeckol in Ethanol-Treated Mice: Possible Involvement of the Inhibition of Acetylcholinesterase. Arch. Pharm. Res. 2005, 28, 691-698. [CrossRef]

99. Negara, B.F.S.P.; Sohn, J.H.; Kim, J.-S.; Choi, J.-S. Effects of Phlorotannins on Organisms: Focus on the Safety, Toxicity, and Availability of Phlorotannins. Foods 2021, 10, 452. [CrossRef]

100. Lin, L.; Yang, S.; Xiao, Z.; Hong, P.; Sun, S.; Zhou, C.; Qian, Z.J. The Inhibition Effect of the Seaweed Polyphenol, 7-Phloro-Eckol from Ecklonia cava on Alcohol-Induced Oxidative Stress in HepG2/CYP2E1 Cells. Mar. Drugs 2021, 19, 158. [CrossRef]

101. Lee, S.H.; Min, K.H.; Han, J.S.; Lee, D.H.; Park, D.B.; Jung, W.K.; Park, P.J.; Jeon, B.T.; Kim, S.K.; Jeon, Y.J. Effects of brown alga, Ecklonia cava on glucose and lipid metabolism in C57BL/KsJ-db/db mice, a model of type 2 diabetes mellitus. Food Chem. Toxicol. 2012, 50, 575-582. [CrossRef]

102. Kang, M.C.; Wijesinghe, W.A.J.P.; Lee, S.H.; Kang, S.M.; Ko, S.C.; Yang, X.; Kang, N.; Jeon, B.T.; Kim, J.; Lee, D.H.; et al. Dieckol isolated from brown seaweed Ecklonia cava attenuates type II diabetes in $\mathrm{db} / \mathrm{db}$ mouse model. Food Chem. Toxicol. 2013, 53, 294-298. [CrossRef]

103. Bhatt, T.; Patel, K. Carotenoids: Potent to Prevent Diseases Review. Nat. Prod. Bioprospect. 2020, 10, 109-117. [CrossRef]

104. Kong, Z.L.; Sudirman, S.; Hsu, Y.C.; Su, C.Y.; Kuo, H.P. Fucoxanthin-rich brown algae extract improves male reproductive function on streptozotocin- nicotinamide-induced diabetic rat model. Int. J. Mol. Sci. 2019, 20, 4485. [CrossRef]

105. Grasa-López, A.; Miliar-García, Á.; Quevedo-Corona, L.; Paniagua-Castro, N.; Escalona-Cardoso, G.; Reyes-Maldonado, E.; Jaramillo-Flores, M.E. Undaria pinnatifida and fucoxanthin ameliorate lipogenesis and markers of both inflammation and cardiovascular dysfunction in an animal model of diet-induced obesity. Mar. Drugs 2016, 14, 148. [CrossRef]

106. Paudel, P.; Seong, S.H.; Jung, H.A.; Choi, J.S. Characterizing fucoxanthin as a selective dopamine D3/D4 receptor agonist: Relevance to Parkinson's disease. Chem. Biol. Interact. 2019, 310, 108757. [CrossRef]

107. Yu, J.; Lin, J.J.; Yu, R.; He, S.; Wang, Q.W.; Cui, W.; Zhang, J.R. Fucoxanthin prevents H2O2-induced neuronal apoptosis via concurrently activating the PI3-K/Akt cascade and inhibiting the ERK pathway. Food Nutr. Res. 2017, 61, 1304678. [CrossRef]

108. Takaichi, S. Carotenoids in Algae: Distributions, Biosyntheses and Functions. Mar. Drugs 2011, 9, 1101-1118. [CrossRef]

109. Li, Z.; Zheng, J.; Luo, X.; Manabe, Y.; Hirata, T. Absorption and Tissue Distribution of Siphonaxanthin from Green Algae. Mar Drugs 2020, 18, 291. [CrossRef]

110. Ziółkowska, N.E.; Wlodawer, A. Structural studies of algal lectins with anti-HIV activity. Acta Biochim. Pol. 2006, 53, 617-626. [CrossRef]

111. Freire, M.; Alves, D.A.; Kalline, F.; Barreto, D.A.; De Vasconcelos, M.A.; Gonzaga, L.; Carneiro, R.F.; Torquato, L.; Nagano, C.S.; Sampaio, A.H.; et al. Antihyperglycemic and antioxidant activities of a lectin from the marine red algae, Bryothamnion seaforthii, in rats with streptozotocin-induced diabetes. Int. J. Biol. Macromol. 2020, 158, 773-780. [CrossRef]

112. Line, R.; Vasconcelos, H.; Rocha, D.; Ramos, A.; Freitas, D.; Cavalcante, J.; Ariévilo, J.; Rodrigues, G.; Maria, K.; Pereira, A.; et al. International Immunopharmacology A lectin from the green seaweed Caulerpa cupressoides reduces mechanical hyper-nociception and in $\mathrm{fl}$ ammation in the rat temporomandibular joint during zymosan-induced arthritis. Int. Immunopharmacol. 2014, 21, 34-43. [CrossRef]

113. De Souza, É.T.; De Lira, D.P.; De Queiroz, A.C.; Da Silva, D.J.C.; De Aquino, A.B.; Mella, E.A.C.; Lorenzo, V.P.; De Miranda, G.E.C.; De Araújo-Júnior, J.X.; Chaves, M.C.D.O.; et al. The antinociceptive and anti-inflammatory activities of caulerpin, a bisindole alkaloid isolated from seaweeds of the genus Caulerpa. Mar. Drugs 2009, 7, 689-704. [CrossRef] 
114. Liu, D.Q.; Mao, S.C.; Zhang, H.Y.; Yu, X.Q.; Feng, M.T.; Wang, B.; Feng, L.H.; Guo, Y.W. Racemosins A and B, two novel bisindole alkaloids from the green alga Caulerpa racemosa. Fitoterapia 2013, 91, 15-20. [CrossRef]

115. Mickymaray, S.; Alturaiki, W. Antifungal efficacy of marine macroalgae against fungal isolates from bronchial asthmatic cases. Molecules 2018, 23, 3032. [CrossRef]

116. Silva, J.; Alves, C.; Freitas, R.; Martins, A.; Pinteus, S.; Ribeiro, J.; Gaspar, H.; Alfonso, A.; Pedrosa, R. Antioxidant and Neuroprotective Potential of the Brown Seaweed Bifurcaria bifurcata in an in vitro Parkinson's Disease Model. Mar. Drugs 2019, 17, 85. [CrossRef]

117. Ghannam, A.; Murad, H.; Jazzara, M.; Odeh, A.; Allaf, A.W. Isolation, Structural characterization, and antiproliferative activity of phycocolloids from the red seaweed Laurencia papillosa on MCF-7 human breast cancer cells. Int. J. Biol. Macromol. 2018, 108, 916-926. [CrossRef]

118. Shamsabadi, F.T.; Khoddami, A.; Fard, S.G.; Abdullah, R.; Othman, H.H.; Mohamed, S. Comparison of tamoxifen with edible seaweed (Eucheuma cottonii L.) Extract in suppressing breast tumor. Nutr. Cancer 2013, 65, 255-262. [CrossRef]

119. Smyrniotopoulos, V.; Merten, C.; Firsova, D.; Fearnhead, H.; Tasdemir, D. Oxygenated Acyclic Diterpenes with Anticancer Activity from the Irish Brown Seaweed Bifurcaria bifurcata. Mar. Drugs 2020, 18, 581. [CrossRef]

120. Lakshmi, T.P.; Vajravijayan, S.; Moumita, M.; Sakthivel, N.; Gunasekaran, K.; Krishna, R. A novel guaiane sesquiterpene derivative, guai-2-en-10 $\alpha$-ol, from Ulva fasciata Delile inhibits EGFR/PI3K/Akt signaling and induces cytotoxicity in triple-negative breast cancer cells. Mol. Cell. Biochem. 2018, 438, 123-139. [CrossRef]

121. Abd-Ellatef, G.E.F.; Ahmed, O.M.; Abdel-Reheim, E.S.; Abdel-Hamid, A.H.Z. Ulva lactuca polysaccharides prevent Wistar rat breast carcinogenesis through the augmentation of apoptosis, enhancement of antioxidant defense system, and suppression of inflammation. Breast Cancer Targets Ther. 2017, 9, 67-83. [CrossRef]

122. Song, J.; Won, S.Y.; Hwang, B.; Jung, S.; Choi, C. In Vitro and In Vivo Antitumor Efficacy of Hizikia fusiforme Celluclast Extract against. Nutrients 2020, 12, 2159. [CrossRef]

123. Tian, L.; Li, C.M.; Li, Y.F.; Huang, T.M.; Chao, N.X.; Luo, G.R.; Mo, F.R. Laminarin from Seaweed (Laminaria japonica) Inhibits Hepatocellular Carcinoma Through Upregulating Senescence Marker Protein-30. Cancer Biother. Radiopharm. 2020, 35, 277-283. [CrossRef]

124. Kim, I.H.; Nam, T.J. Fucoidan downregulates insulin-like growth factor-I receptor levels in HT-29 human colon cancer cells. Oncol. Rep. 2018, 39, 1516-1522. [CrossRef]

125. Cotas, J.; Marques, V.; Afonso, M.B.; Rodrigues, C.M.P.; Pereira, L. Antitumour potential of Gigartina pistillata carrageenans against colorectal cancer stem cell-enriched tumourspheres. Mar. Drugs 2020, 18, 50. [CrossRef]

126. Lins, K.O.A.L.; Bezerra, D.P.; Alves, A.P.N.N.; Alencar, N.M.N.; Lima, M.W.; Torres, V.M.; Farias, W.R.L.; Pessoa, C.; De Moraes, M.O.; Costa-Lotufo, L.V. Antitumor properties of a sulfated polysaccharide from the red seaweed Champia feldmannii (Diaz-Pifferer). J. Appl. Toxicol. 2009, 29, 20-26. [CrossRef]

127. Sae-lao, T.; Luplertlop, N.; Janvilisri, T.; Tohtong, R.; Bates, D.O.; Wongprasert, K. Sulfated galactans from the red seaweed Gracilaria fisheri exerts anti-migration effect on cholangiocarcinoma cells. Phytomedicine 2017, 36, 59-67. [CrossRef] [PubMed]

128. Delgado-Roche, L.; Rodeiro, I.; Riera, M.; Herrera, J.A.; Venturi, I.; Hernández, Y.; Fernández, G.; Pérez, C.L.; Rodriguez, J.C.; Fernández, M.D.; et al. Chemoprotective effects of Ulva lactuca (green seaweed) aqueous-ethanolic extract against subchronic exposure to benzo(a)pyrene by CYP1A1 inhibition in mice. Phytother. Res. 2019, 33, 958-967. [CrossRef] [PubMed]

129. Ropellato, J.; Carvalho, M.M.; Ferreira, L.G.; Noseda, M.D.; Zuconelli, C.R.; Gonçalves, A.G.; Ducatti, D.R.B.; Kenski, J.C.N.; Nasato, P.L.; Winnischofer, S.M.B.; et al. Sulfated heterorhamnans from the green seaweed Gayralia oxysperma: Partial depolymerization, chemical structure and antitumor activity. Carbohydr. Polym. 2015, 117, 476-485. [CrossRef] [PubMed]

130. Kim, S.; Lee, M.S.; Lee, B.; Gwon, W.G.; Joung, E.J.; Yoon, N.Y.; Kim, H.R. Anti-inflammatory effects of sargachromenol-rich ethanolic extract of Myagropsis myagroides on lipopolysaccharide-stimulated BV-2 cells. BMC Complement. Altern. Med. 2014, 14, 231. [CrossRef]

131. Tarozzi, A.; Angeloni, C.; Malaguti, M.; Morroni, F.; Hrelia, S.; Hrelia, P. Sulforaphane as a Potential Protective Phytochemical against Neurodegenerative Diseases. Oxid. Med. Cell. Longev. 2013, 2013, 415078. [CrossRef]

132. Barbalace, M.C.; Malaguti, M.; Giusti, L.; Lucacchini, A.; Hrelia, S.; Angeloni, C. Anti-inflammatory activities of marine algae in neurodegenerative diseases. Int. J. Mol. Sci. 2019, 20, 3061. [CrossRef]

133. Kim, J.; Moon, I.S.; Goo, T.; Moon, S.; Seo, M. Algae Undaria pinnatifida Protects Hypothalamic Neurons against Endoplasmic Reticulum Stress through Akt/mTOR Signaling. Molecules 2015, 20, 20998-21009. [CrossRef]

134. Jung, H.A.; Ali, M.Y.; Choi, R.J.; Jeong, H.O.; Chung, H.Y.; Choi, J.S. Kinetics and molecular docking studies of fucosterol and fucoxanthin, BACE1 inhibitors from brown algae Undaria pinnatifida and Ecklonia stolonifera. Food Chem. Toxicol. 2016, 89, 104-111. [CrossRef]

135. Kim, T.E.; Son, H.J.; Lim, D.W.; Yoon, M.; Lee, J.; Kim, Y.T.; Han, D.; Lee, C.; Um, M.Y. Memory-enhancing effects of Ishige foliacea extract: In vitro and in vivo study. J. Food Biochem. 2020, 44, e13162. [CrossRef]

136. Kim, J.H.; Lee, N.S.; Jeong, Y.G.; Lee, J.-H.; Kim, E.J.; Han, S.Y. Protective efficacy of an Ecklonia cava extract used to treat transient focal ischemia of the rat brain. Anat. Cell Biol. 2012, 45, 103. [CrossRef]

137. Kang, I.J.; Jeon, Y.E.; Yin, X.F.; Nam, J.S.; You, S.G.; Hong, M.S.; Jang, B.G.; Kim, M.J. Butanol extract of Ecklonia cava prevents production and aggregation of beta-amyloid, and reduces beta-amyloid mediated neuronal death. Food Chem. Toxicol. 2011, 49, 2252-2259. [CrossRef] [PubMed] 
138. Kang, I.J.; Jang, B.G.; In, S.; Choi, B.; Kim, M.; Kim, M.J. Phlorotannin-rich Ecklonia cava reduces the production of beta-amyloid by modulating alpha- and gamma-secretase expression and activity. Neurotoxicology 2013, 34, 16-24. [CrossRef]

139. Kwon, O.Y.; Lee, S.H. Ameliorating Activity of Ishige okamurae on the Amyloid Beta-Induced Cognitive Deficits and Neurotoxicity through Regulating ERK, p38 MAPK, and JNK Signaling in Alzheimer's Disease-Like Mice Model. Mol. Nutr. Food Res. 2020, 64, e1901220. [CrossRef]

140. Olasehinde, T.A.; Olaniran, A.O.; Okoh, A.I. Phenolic composition, antioxidant activity, anticholinesterase potential and modulatory effects of aqueous extracts of some seaweeds on $\beta$-amyloid aggregation and disaggregation. Pharm. Biol. 2019, 57, 460-469. [CrossRef] [PubMed]

141. Souza, R.B.; Frota, A.F.; Sousa, R.S.; Cezario, N.A.; Santos, T.B.; Souza, L.M.F.; Coura, C.O.; Monteiro, V.S.; Filho, G.C.; Vasconcelos, S.M.M.; et al. Neuroprotective Effects of Sulphated Agaran from Marine Alga Gracilaria cornea in Rat 6Hydroxydopamine Parkinson's Disease Model: Behavioural, Neurochemical and Transcriptional Alterations. Basic Clin. Pharmacol. Toxicol. 2017, 120, 159-170. [CrossRef] [PubMed]

142. Hannan, M.A.; Kang, J.Y.; Hong, Y.K.; Lee, H.; Choi, J.S.; Choi, I.S.; Moon, I.S. The marine alga Gelidium amansii promotes the development and complexity of neuronal cytoarchitecture. Phyther. Res. 2013, 27, 21-29. [CrossRef]

143. Kim, M.J.; Li, Y.X.; Dewapriya, P.; Ryu, B.; Kim, S.K. Floridoside suppresses pro-inflammatory responses by blocking MAPK signaling in activated microglia. BMB Rep. 2013, 46, 398-403. [CrossRef]

144. Pereira, L.; Valado, A. The Seaweed Diet in Prevention and Treatment of the. Mar. Drugs 2021, 19, 128. [CrossRef]

145. Niizuma, K.; Endo, H.; Chan, P.H. Oxidative stress and mitochondrial dysfunction as determinants of ischemic neuronal death and survival. J. Neurochem. 2009, 109, 133-138. [CrossRef]

146. Ramkumar, M.; Rajasankar, S.; Gobi, V.V.; Dhanalakshmi, C.; Manivasagam, T.; Justin Thenmozhi, A.; Essa, M.M.; Kalandar, A.; Chidambaram, R. Neuroprotective effect of Demethoxycurcumin, a natural derivative of Curcumin on rotenone induced neurotoxicity in SH-SY 5Y Neuroblastoma cells. BMC Complement. Altern. Med. 2017, 17, 217. [CrossRef]

147. Ward, R.J.; Zucca, F.A.; Duyn, J.H.; Crichton, R.R.; Zecca, L. The role of iron in brain ageing and neurodegenerative disorders. Lancet Neurol. 2014, 13, 1045-1060. [CrossRef]

148. Li, K.; Reichmann, H. Role of iron in neurodegenerative diseases. J. Neural Transm. 2016, 123, 389-399. [CrossRef]

149. Silva, J.; Alves, C.; Pinteus, S.; Mendes, S.; Pedrosa, R. Seaweeds' neuroprotective potential set in vitro on a human cellular stress model. Mol. Cell. Biochem. 2020, 473, 229-238. [CrossRef] [PubMed]

150. Waly, M.I.; Al Alawi, A.A.; Al Marhoobi, I.M.; Rahman, M.S. Red seaweed (Hypnea bryodies and Melanothamnus somalensis) extracts counteracting azoxymethane-induced hepatotoxicity in rats. Asian Pac. J. Cancer Prev. 2016, 17, 5071-5074. [CrossRef] [PubMed]

151. Sohail, N.; Hira, K.; Tariq, A.; Sultana, V.; Ehteshamul-Haque, S. Marine macro-algae attenuates nephrotoxicity and hepatotoxicity induced by cisplatin and acetaminophen in rats. Environ. Sci. Pollut. Res. 2019, 26, 25301-25311. [CrossRef] [PubMed]

152. Wong, C.K.; Ooi, V.E.C.; Ang, P.O. Protective effects of seaweeds against liver injury caused by carbon tetrachloride in rats. Chemosphere 2000, 41, 173-176. [CrossRef]

153. Tsai, M.Y.; Yang, W.C.; Lin, C.F.; Wang, C.M.; Liu, H.Y.; Lin, C.S.; Lin, J.W.; Lin, W.L.; Lin, T.C.; Fan, P.S.; et al. The ameliorative effects of fucoidan in thioacetaide-induced liver injury in mice. Molecules 2021, 26, 1937. [CrossRef] [PubMed]

154. Gabbia, D.; Dall'Acqua, S.; Di Gangi, I.M.; Bogialli, S.; Caputi, V.; Albertoni, L.; Marsilio, I.; Paccagnella, N.; Carrara, M.; Giron, M.C.; et al. The Phytocomplex from Fucus vesiculosus and ascophyllum nodosum controls postprandial plasma glucose levels: An in vitro and in Vivo study in a mouse model of NASH. Mar. Drugs 2017, 15, 41. [CrossRef]

155. Thomes, P.; Rajendran, M.; Pasanban, B.; Rengasamy, R. Phytomedicine Cardioprotective activity of Cladosiphon okamuranus fucoidan against isoproterenol induced myocardial infarction in rats. Eur. J. Integr. Med. 2010, 18, 52-57. [CrossRef]

156. Cha, S.H.; Hwang, Y.; Heo, S.J.; Jun, H.S. Indole-4-carboxaldehyde Isolated from Seaweed, Sargassum thunbergii, Attenuates Methylglyoxal-Induced Hepatic Inflammation. Mar. Drugs 2019, 17, 486. [CrossRef]

157. Jin, M.; Liu, H.; Hou, Y.; Chan, Z.; Di, W.; Li, L.; Zeng, R. Preparation, characterization and alcoholic liver injury protective effects of algal oligosaccharides from Gracilaria lemaneiformis. Food Res. Int. 2017, 100, 186-195. [CrossRef] [PubMed]

158. Lieber, S. Alcohol and the Liver: 1994 Update. Gastroenterology 1994, 106, 1085-1105. [CrossRef]

159. Heeba, G.H.; Morsy, M.A. Fucoidan ameliorates steatohepatitis and insulin resistance by suppressing oxidative stress and inflammatory cytokines in experimental non-alcoholic fatty liver disease. Environ. Toxicol. Pharmacol. 2015, 40, 907-914. [CrossRef] [PubMed]

160. Friedman, S.L.; Neuschwander-Tetri, B.A.; Rinella, M.; Sanyal, A.J. Mechanisms of NAFLD development and therapeutic strategies. Nat. Med. 2018, 24, 908-922. [CrossRef]

161. Takatani, N.; Kono, Y.; Beppu, F.; Okamatsu-Ogura, Y.; Yamano, Y.; Miyashita, K.; Hosokawa, M. Fucoxanthin inhibits hepatic oxidative stress, inflammation, and fibrosis in diet-induced nonalcoholic steatohepatitis model mice. Biochem. Biophys. Res. Commun. 2020, 528, 305-310. [CrossRef]

162. Jia, R.; Li, Z.; Wu, J.; Ou, Z.; Liao, B.; Sun, B.; Lin, L.; Zhao, M. Mitigation mechanisms of Hizikia fusifarme polysaccharide consumption on type 2 diabetes in rats. Int. J. Biol. Macromol. 2020, 164, 2659-2670. [CrossRef]

163. Yang, T.H.; Yao, H.T.; Chiang, M.T. Red algae (Gelidium amansii) reduces adiposity via activation of lipolysis in rats with diabetes induced by streptozotocin-nicotinamide. J. Food Drug Anal. 2015, 23, 758-765. [CrossRef]

164. Yokogawa, K.; Matsui-Yuasa, I.; Tamura, A.; Terada, M.; Kojima-Yuasa, A. Inhibitory effects of Ecklonia cava extract on high glucose-induced hepatic stellate cell activation. Mar. Drugs 2011, 9, 2793-2808. [CrossRef] 
165. Lin, H.T.V.; Tsou, Y.C.; Chen, Y.T.; Lu, W.J.; Hwang, P.A. Effects of low-molecular-weight fucoidan and high stability fucoxanthin on glucose homeostasis, lipid metabolism, and liver function in a mouse model of type II diabetes. Mar. Drugs 2017, 15, 113. [CrossRef]

166. Yu, W.-C.; Huang, R.-Y.; Chou, T.-C. Oligo-Fucoidan Improves Diabetes-Induced Renal Fibrosis via Activation of Sirt-1, GLP-1R, and Nrf2/HO-1: An In Vitro and In Vivo Study. Nutrients 2020, 12, 3068. [CrossRef]

167. Park, M.H.; Han, J.S. Padina arborescens Ameliorates Hyperglycemia and Dyslipidemia in C57BL/KsJ-db/db Mice, a Model of Type 2 Diabetes Mellitus. J. Med. Food 2015, 18, 1088-1094. [CrossRef]

168. Attjioui, M.; Ryan, S.; Ristic, A.K.; Higgins, T.; Goñi, O.; Gibney, E.R.; Tierney, J.; O'Connell, S. Comparison of edible brown algae extracts for the inhibition of intestinal carbohydrate digestive enzymes involved in glucose release from the diet. J. Nutr. Sci. 2021, 10, e5. [CrossRef] [PubMed]

169. Kim, K.T.; Rioux, L.E.; Turgeon, S.L. Alpha-amylase and alpha-glucosidase inhibition is differentially modulated by fucoidan obtained from Fucus vesiculosus and Ascophyllum nodosum. Phytochemistry 2014, 98, 27-33. [CrossRef] [PubMed]

170. Lee, S.H.; Kang, S.M.; Ko, S.C.; Lee, D.H.; Jeon, Y.J. Octaphlorethol A, a novel phenolic compound isolated from a brown alga, Ishige foliacea, increases glucose transporter 4-mediated glucose uptake in skeletal muscle cells. Biochem. Biophys. Res. Commun. 2012, 420, 576-581. [CrossRef] [PubMed]

171. Lee, S.H.; Ko, S.C.; Kang, M.C.; Lee, D.H.; Jeon, Y.J. Octaphlorethol A, a marine algae product, exhibits antidiabetic effects in type 2 diabetic mice by activating AMP-activated protein kinase and upregulating the expression of glucose transporter 4 . Food Chem. Toxicol. 2016, 91, 58-64. [CrossRef] [PubMed]

172. Motshakeri, M.; Ebrahimi, M.; Goh, Y.M.; Othman, H.H.; Hair-bejo, M.; Mohamed, S. Effects of Brown Seaweed (Sargassum polycystum) Extracts on Kidney, Liver, and Pancreas of Type 2 Diabetic Rat Model. Evid. Based Complement. Altern. Med. 2014, 2014, 379407. [CrossRef]

173. Jia, R.B.; Wu, J.; Li, Z.R.; Ou, Z.R.; Lin, L.; Sun, B.; Zhao, M. Structural characterization of polysaccharides from three seaweed species and their hypoglycemic and hypolipidemic activities in type 2 diabetic rats. Int. J. Biol. Macromol. 2020, 155, 1040-1049. [CrossRef]

174. Moon, H.E.; Islam, M.N.; Ahn, B.R.; Chowdhury, S.S.; Sohn, H.S.; Jung, H.A.; Choi, J.S. Protein tyrosine phosphatase 1B and $\alpha$-glucosidase inhibitory phlorotannins from edible brown algae, Ecklonia stolonifera and Eisenia bicyclis. Biosci. Biotechnol. Biochem. 2011, 75, 1472-1480. [CrossRef]

175. Tas, S.; Celikler, S.; Ziyanok-Ayvalik, S.; Sarandol, E.; Dirican, M. Ulva rigida improves carbohydrate metabolism, hyperlipidemia and oxidative stress in streptozotocin-induced diabetic rats. Cell Biochem. Funct. 2011, 29, 108-113. [CrossRef]

176. Baron, A.D. Postprandial hyperglycaemia and $\alpha$-glucosidase inhibitors. Diabetes Res. Clin. Pract. 1998, 40, 51-55. [CrossRef]

177. Snijder, M.B.; Zimmet, P.Z.; Visser, M.; Dekker, J.M.; Seidell, J.C.; Shaw, J.E. Independent and opposite associations of waist and hip circumferences with diabetes, hypertension and dyslipidemia: The AusDiab Study. Int. J. Obes. 2004, 28, 402-409. [CrossRef] [PubMed]

178. Calle, E.E.; Thun, M.J. Obesity and cancer. Oncogene 2004, 23, 6365-6378. [CrossRef] [PubMed]

179. Kim, D.S.; Lee, S.G.; Kim, M.; Hahn, D.; Jung, S.K.; Cho, T.O.; Nam, J.O. Sargassum miyabei yendo brown algae exert anti-oxidative and anti-adipogeniceffects on 3t3-11 adipocytes by downregulating ppar $\gamma$. Medicina 2020, 56, 634. [CrossRef] [PubMed]

180. Huebbe, P.; Nikolai, S.; Schloesser, A.; Herebian, D.; Glüer, C.; Zeyner, A.; Demetrowitsch, T.; Metges, C.C.; Roeder, T.; Schultheiss, G.; et al. An extract from the Atlantic brown algae Saccorhiza polyschides counteracts diet-induced obesity in mice via a gut related multi-factorial mechanisms. Oncotarget 2017, 8, 73501-73515. [CrossRef]

181. Park, M.K.; Jung, U.; Roh, C. Fucoidan from marine brown algae inhibits lipid accumulation. Mar. Drugs 2011, 9, 1359-1367. [CrossRef]

182. Kang, S.I.; Kim, M.H.; Shin, H.S.; Kim, H.M.; Hong, Y.S.; Park, J.G.; Ko, H.C.; Lee, N.H.; Chung, W.S.; Kim, S.J. A water-soluble extract of Petalonia binghamiae inhibits the expression of adipogenic regulators in 3T3-L1 preadipocytes and reduces adiposity and weight gain in rats fed a high-fat diet. J. Nutr. Biochem. 2010, 21, 1251-1257. [CrossRef]

183. Jung, H.A.; Jung, H.J.; Jeong, H.Y.; Kwon, H.J.; Kim, M.S.; Choi, J.S. Anti-adipogenic activity of the edible brown alga Ecklonia stolonifera and its constituent fucosterol in 3T3-L1 adipocytes. Arch. Pharm. Res. 2014, 37, 713-720. [CrossRef]

184. Lee, J.H.; Jung, H.A.; Kang, M.J.; Choi, J.S.; Kim, G. Do Fucosterol, isolated from Ecklonia stolonifera, inhibits adipogenesis through modulation of FoxO1 pathway in 3T3-L1 adipocytes. J. Pharm. Pharmacol. 2017, 69, 325-333. [CrossRef]

185. Karadeniz, F.; Ahn, B.N.; Kim, J.A.; Seo, Y.; Jang, M.S.; Nam, K.H.; Kim, M.; Lee, S.H.; Kong, C.S. Phlorotannins suppress adipogenesis in pre-adipocytes while enhancing osteoblastogenesis in pre-osteoblasts. Arch. Pharm. Res. 2015, 38, $2172-2182$. [CrossRef]

186. Eo, H.; Jeon, Y.J.; Lee, M.; Lim, Y. Brown alga Ecklonia cava polyphenol extract ameliorates hepatic lipogenesis, oxidative stress, and inflammation by activation of AMPK and SIRT1 in high-fat diet-induced obese mice. J. Agric. Food Chem. 2015, 63, 349-359. [CrossRef]

187. Kang, J.H.; Lee, H.A.; Kim, H.J.; Han, J.S. Gelidium amansii extract ameliorates obesity by down-regulating adipogenic transcription factors in diet-induced obese mice. Nutr. Res. Pract. 2017, 11, 17-24. [CrossRef] [PubMed]

188. Kang, M.C.; Kang, N.; Ko, S.C.; Kim, Y.B.; Jeon, Y.J. Anti-obesity effects of seaweeds of Jeju Island on the differentiation of 3T3-L1 preadipocytes and obese mice fed a high-fat diet. Food Chem. Toxicol. 2016, 90, 36-44. [CrossRef] [PubMed] 
189. Zheng, J.; Manabe, Y.; Sugawara, T. Siphonaxanthin, a carotenoid from green algae Codium cylindricum, protects Ob/Ob mice fed on a high-fat diet against lipotoxicity by ameliorating somatic stresses and restoring anti-oxidative capacity. Nutr. Res. 2020, 77, 29-42. [CrossRef] [PubMed]

190. Sudirman, S.; Chang, H.W.; Chen, C.K.; Kong, Z.L. A dietary polysaccharide from: Eucheuma cottonii downregulates proinflammatory cytokines and ameliorates osteoarthritis-associated cartilage degradation in obese rats. Food Funct. 2019, 10, 5697-5706. [CrossRef]

191. Du Preez, R.; Majzoub, M.E.; Thomas, T.; Panchal, S.K.; Brown, L. Caulerpa lentillifera (Sea grapes) improves cardiovascular and metabolic health of rats with diet-induced metabolic syndrome. Metabolites 2020, 10, 500. [CrossRef]

192. Yuan, X.; Nakao, T.; Satone, H.; Ohara, K.; Kominami, Y.; Ito, M.; Aizawa, T.; Ueno, T.; Ushio, H. The effects of brown algae-derived monosaccharide l-fucose on lipid metabolism in c57bl/6j obese mice. Nutrients 2020, 12, 3798. [CrossRef]

193. Kishida, R.; Yamagishi, K.; Muraki, I.; Sata, M.; Tamakoshi, A.; Iso, H. Frequency of Seaweed Intake and Its Association with Cardiovascular Disease Mortality: The JACC Study. J. Atheroscler. Thromb. 2020, 27, 1340-1347. [CrossRef]

194. Cardoso, S.M.; Pereira, O.R.; Seca, A.M.L.; Pinto, D.C.G.A.; Silva, A.M.S. Seaweeds as preventive agents for cardiovascular diseases: From nutrients to functional foods. Mar. Drugs 2015, 13, 6838-6865. [CrossRef]

195. Ren, D.; Wang, Q.; Yang, Y.; Hu, Y.; Song, Y.; He, Y.; Liu, S.; Wu, L. Hypolipidemic effects of fucoidan fractions from Saccharina sculpera (Laminariales, Phaeophyceae). Int. J. Biol. Macromol. 2019, 140, 188-195. [CrossRef]

196. Ara, J.; Sultana, V.; Qasim, R.; Ahmad, V.U. Hypolipidaemic activity of seaweed from Karachi coast. Phytother. Res. 2002, 16, 479-483. [CrossRef]

197. Yang, Z.; Yin, J.; Wang, Y.; Wang, J.; Xia, B.; Li, T.; Yang, X.; Hu, S.; Ji, C.; Guo, S. The fucoidan A3 from the seaweed Ascophyllum nodosum enhances RCT-related genes expression in hyperlipidemic C57BL/6J mice. Int. J. Biol. Macromol. 2019, 134, 759-769. [CrossRef] [PubMed]

198. Ahn, H.S.; Lee, D.H.; Kim, T.J.; Shin, H.C.; Jeon, H.K. Cardioprotective Effects of a Phlorotannin Extract Against DoxorubicinInduced Cardiotoxicity in a Rat Model. J. Med. Food 2017, 20, 944-950. [CrossRef] [PubMed]

199. Paiva, L.; Lima, E.; Neto, A.I.; Baptista, J. Angiotensin I-converting enzyme (ACE) inhibitory activity, antioxidant properties, phenolic content and amino acid profiles of fucus spiralis L. Protein hydrolysate fractions. Mar. Drugs 2017, 15, 311. [CrossRef] [PubMed]

200. Park, B.G.; Shin, W.S.; Oh, S.; Park, G.M.; Kim, N.I.; Lee, S. A novel antihypertension agent, sargachromenol D from marine brown algae, Sargassum siliquastrum, exerts dual action as an L-type $\mathrm{Ca}^{2+}$ channel blocker and endothelin A/B2 receptor antagonist. Bioorg. Med. Chem. 2017, 25, 4649-4655. [CrossRef]

201. Yeo, A.R.; Lee, J.; Tae, I.H.; Park, S.R.; Cho, Y.H.; Lee, B.H.; Shin, H.C.; Kim, S.H.; Yoo, Y.C. Anti-hyperlipidemic effect of polyphenol extract (Seapolynol ${ }^{\mathrm{TM}}$ ) and dieckol isolated from Ecklonia cava in in vivo and in vitro models. Prev. Nutr. Food Sci. 2012, 17, 1-7. [CrossRef]

202. Zhang, Q.; Fan, X.Y.; Guo, W.L.; Cao, Y.J.; Lin, Y.C.; Cheng, W.J.; Chen, L.J.; Rao, P.F.; Ni, L.; Lv, X.C. The protective mechanisms of macroalgae: Laminaria japonica consumption against lipid metabolism disorders in high-fat diet-induced hyperlipidemic rats. Food Funct. 2020, 11, 3256-3270. [CrossRef]

203. Ryu, B.M.; Li, Y.; Qian, Z.J.; Kim, M.M.; Kim, S.K. Differentiation of human osteosarcoma cells by isolated phlorotannins is subtly linked to COX-2, iNOS, MMPs, and MAPK signaling: Implication for chronic articular disease. Chem. Biol. Interact. 2009, 179, 192-201. [CrossRef]

204. Lee, D.; Hwang, E.; Park, S.; Chung, W.; Park, J.; Mavlonov, G.T.; Kim, I.; Kim, K.; Yi, T. Fucoidan Prevents the Progression of Osteoarthritis in Rats. J. Med. Food 2015, 18, 1032-1041. [CrossRef]

205. Stoustrup, P.; Lerman, M.A.; Twilt, M. The Temporomandibular Joint in Juvenile Idiopathic Arthritis. Rheum. Dis. Clin. N. Am. 2021, 47, 607-617. [CrossRef]

206. Poddubnyy, D.; Jadon, D.R.; Bosch, F.V.D.; Mease, P.J.; Gladman, D.D. Axial involvement in psoriatic arthritis: An update for rheumatologists. Semin. Arthritis Rheum. 2021, 51, 880-887. [CrossRef]

207. Patil, T.; Soni, A.; Acharya, S. A brief review on in vivo models for Gouty Arthritis. Metab. Open 2021, 11, 100100. [CrossRef] [PubMed]

208. Cush, J.J. Rheumatoid Arthritis: Early Diagnosis and Treatment. Med. Clin. N. Am. 2021, 105, 355-365. [CrossRef]

209. Sun, K.; Luo, J.; Guo, J.; Yao, X.; Jing, X.; Guo, F. The PI3K/AKT/mTOR signaling pathway in osteoarthritis: A narrative review. Osteoarthr. Cartil. 2020, 28, 400-409. [CrossRef] [PubMed]

210. Paiva, A.A.D.O.; Castro, A.J.G.; Nascimento, M.S.; Will, L.S.E.P.; Santos, N.D.; Araújo, R.M.; Xavier, C.A.C.; Rocha, F.A.; Leite, E.L. Antioxidant and anti-inflammatory effect of polysaccharides from Lobophora variegata on zymosan-induced arthritis in rats. Int. Immunopharmacol. 2011, 11, 1241-1250. [CrossRef] [PubMed]

211. Sarithakumari, C.H.; Renju, G.L.; Kurup, G.M. Anti-inflammatory and antioxidant potential of alginic acid isolated from the marine algae, Sargassum wightii on adjuvant-induced arthritic rats. Inflammopharmacology 2013, 21, 261-268. [CrossRef] [PubMed]

212. Chatter, R.; Ben Othman, R.; Rabhi, S.; Kladi, M.; Tarhouni, S.; Vagias, C.; Roussis, V.; Guizani-Tabbane, L.; Kharrat, R. In vivo and in vitro anti-inflammatory activity of neorogioltriol, a new diterpene extracted from the red algae Laurencia glandulifera. Mar. Drugs 2011, 9, 1293-1306. [CrossRef] [PubMed] 
213. Moon, S.M.; Lee, S.A.; Hong, J.H.; Kim, J.S.; Kim, D.K.; Kim, C.S. Oleamide suppresses inflammatory responses in LPSinduced RAW264.7 murine macrophages and alleviates paw edema in a carrageenan-induced inflammatory rat model. Int. Immunopharmacol. 2018, 56, 179-185. [CrossRef]

214. Lacey, D.C.; Simmons, P.J.; Graves, S.E.; Hamilton, J.A. Proinflammatory cytokines inhibit osteogenic differentiation from stem cells: Implications for bone repair during inflammation. Osteoarthr. Cartil. 2009, 17, 735-742. [CrossRef]

215. Nekooei, M.; Shafiee, S.M.; Zahiri, M.; Maryamabadi, A.; Nabipour, I. The methanol extract of red algae, Dichotomaria obtusata from Persian Gulf promotes in vitro osteogenic differentiation of bone marrow mesenchymal stem cells; A biological and phytochemical study. J. Pharm. Pharmacol. 2021, 73, 347-356. [CrossRef]

216. Carson, M.A.; Nelson, J.; Cancela, M.L.; Laizé, V.; Gavaia, P.J.; Rae, M.; Heesch, S.; Verzin, E.; Gilmore, B.F.; Clarke, S.A. Screening for osteogenic activity in extracts from Irish marine organisms: The potential of Ceramium pallidum. PLoS ONE 2018, 13, e0207303. [CrossRef]

217. Fidelis, G.P.; Ferreira Silva, C.H.; Nobre, L.T.D.B.; Medeiros, V.P.; Rocha, H.A.O.; Costa, L.S. Antioxidant fucoidans obtained from tropical seaweed protect pre-osteoblastic cells from hydrogen peroxide-induced damage. Mar. Drugs 2019, 17, 506. [CrossRef] [PubMed]

218. Minetti, M.; Bernardini, G.; Biazzo, M.; Gutierrez, G.; Geminiani, M.; Petrucci, T.; Santucci, A. Padina pavonica Extract Promotes In Vitro Differentiation and Functionality of Human Primary Osteoblasts. Mar. Drugs 2019, 17, 473. [CrossRef] [PubMed]

219. Lu, S.H.; Hsia, Y.J.; Shih, K.C.; Chou, T.C. Fucoidan prevents RANKL-stimulated osteoclastogenesis and LPS-induced inflammatory bone loss via regulation of AKt/GSK3 $\beta$ /PTEN/NFATc1 signaling pathway and calcineurin activity. Mar. Drugs 2019, 17, 345. [CrossRef] [PubMed]

220. Lee, S.H.; Kim, M.; Park, M.H. Diphlorethohydroxycamalol isolated from Ishige okamurae prevents H2O2-induced oxidative damage via BMP2/Runx2 signaling in osteoblastic MC3T3-E1 cells. Fitoterapia 2021, 152, 104921. [CrossRef] [PubMed]

221. Carson, M.A.; Nelson, J.; Cancela, M.L.; Laizé, V.; Gavaia, P.J.; Rae, M.; Heesch, S.; Verzin, E.; Maggs, C.; Gilmore, B.F.; et al. Red algal extracts from Plocamium lyngbyanum and Ceramium secundatum stimulate osteogenic activities in vitro and bone growth in zebrafish larvae. Sci. Rep. 2018, 8, 7725. [CrossRef] [PubMed]

222. Surget, G.; Roberto, V.P.; Le Lann, K.; Mira, S.; Guérard, F.; Laizé, V.; Poupart, N.; Cancela, M.L. Marine green macroalgae: A source of natural compounds with mineralogenic and antioxidant activities. J. Appl. Phycol. 2016, 29, 575-584. [CrossRef]

223. Mironidou-Tzouveleki, M.; Dokos, C.H.; Dokou, K. Effects of extracts of marine algae on osteoporosis. Aristotle Univ. Med. J. 2008, 35, 7-12.

224. Boyle, W.J.; Simonet, W.S.; Lacey, D.L. Osteoclast differentiation and activation. Nature 2003, 423, 337-342. [CrossRef] 